\title{
Incorporating Technetium in Minerals and Other Solids: A Review
}

\author{
Steven A. Luksic, Brian J. Riley, Michael Schweiger, Pavel Hrma
}

Pacific Northwest National Laboratory, Richland WA, 99352

Keywords: technetium, immobilization, waste form, vitrification, spinel, sodalite, rutile, perovskite, pyrochlore

\begin{abstract}
Technetium (Tc) can be incorporated into a number of different solids including spinel, sodalite, rutile, tin dioxide, pyrochlore, perovskite, goethite, layered double hydroxides, cements, and alloys. Synthetic routes are possible for each of these phases, ranging from high-temperature ceramic sintering to ball-milling of constituent oxides. However, in practice, Tc has only been incorporated into solid materials by a limited number of the possible syntheses. A review of the diverse ways in which Tc-immobilizing materials can be made shows the wide range of options available. Special consideration is given to hypothetical application to the Hanford Tank Waste and Vitrification Plant, such as adding a Tc-bearing mineral to waste glass melter feed. A full survey of solid Tc waste forms, the common synthesis routes to those waste forms, and their potential for application to vitrification processes are presented. The use of tin dioxide or ferrite spinel precursors to reduce $\mathrm{Tc}(\mathrm{VII})$ out of solution and into a durable form are shown to be of especially high potential.
\end{abstract}

\section{Introduction}

Some 56 million gallons of waste were produced at the Hanford Site in Washington State as part of the production of plutonium during the last century. This waste currently resides in

\footnotetext{
* Corresponding author: Steven A. Luksic, steven.luksic@pnnl.gov, phone: (509) 375-2376 
carbon steel tanks on the Hanford Site. [1]. Technetium makes up 6\% of the fission products from the use of uranium in the production reactors, and is thus a large part of the legacy waste that must be dealt with. Technetium is long-lived (half-life $=2.13 \times 10^{5} \mathrm{y}$ ) and environmentally mobile in its oxidized form $\left(\mathrm{TcO}_{4}^{-}\right)[2,3]$. These properties add to the U.S. Department of Energy's urgency in immobilizing Hanford tank waste before leaking tanks become an environmental problem. Long-term immobilization of Tc is critical, as Tc is the dominant source of radioactivity in high-level wastes in the range of ten to hundreds of thousands of years [4] (see Figure 1).

The current plan to treat the contents of Hanford tanks is to separate the wastes into a large-volume, low-activity waste (LAW) and a small-volume, high-level waste (HLW) fractions at the Hanford Tank Waste Treatment and Immobilization Plant (WTP), which currently is under construction at the Hanford Site. The LAW and HLW fractions will be vitrified in separate facilities within the WTP. Glass-forming additives and various components of the tank waste will be fed into waste-glass melters operating at temperatures of $1150^{\circ} \mathrm{C}$ to vitrify the waste. One challenge to this approach is that $\mathrm{Tc}$ species, such as $\mathrm{TcO}_{4}{ }_{4}$, are volatile at temperatures below $900^{\circ} \mathrm{C}[5,6]$, and this volatility is accentuated by the high temperatures found in vitrification melters. Volatiles from the melters, including Tc, will be captured in off-gas scrubbing systems that divert Tc, sulfur, and other waste-glass components to a dilute aqueous solution. The volatility of Tc makes it one of the more challenging elements to capture and store safely in glass.

Alternatives to vitrification have been either proposed or are already underway for managing Tc wastes. In some places, Tc was simply released into the ocean [7]. Transmutation of metallic Tc into ruthenium has been attempted by the French with some success [8]. Other 
approaches include the formation of low-temperature waste forms for Tc-containing LAW such as cementitious waste forms [9-11], ceramicrete [10], and products of fluidized bed steam reforming [12].

Another approach to Tc immobilization is to remove the $\mathrm{TcO}_{4}{ }^{-}$from waste so it can be incorporated into a separate waste form. This can be achieved via ion exchange or with Tcgetters $[13,14]$. Qafoku et al. [15] recently investigated materials that could be used to remove $\mathrm{TcO}_{4}{ }^{-}$from solutions via reduction. The Tc then would be immobilized in a separate waste form such as Cast Stone [15].

The final approach discussed here is incorporation of Tc into a mineral lattice that would inhibit its volatility from the melter. If the Tc could be captured in a form that restrains volatility, such a material could transport the technetium into the bulk of the melt where it would be incorporated into the glass and where it would be less able to escape as a volatile gas during vitrification. If the $\mathrm{TcO}_{4}{ }^{-}$expected to be in the waste could be bound in a mineral structure, early experiments [16] show that this approach has the potential to increase Tc retention in the glass.

Technetium is present in very small amounts as a result of natural uranium fission [17] and more recent human activities involving nuclear fission. Many different host mineral phases have been synthesized to include Tc in the mineral structure. These include spinel [18], sodalite [12], pyrochlore [19, 20], perovskites [20], rutile [21], goethite [22, 23], and layered double hydroxides [15, 24, 25]. Additionally, Tc-containing metal alloys have been studied as waste forms for immobilizing Tc [26, 27].

The attributes of these mineral phases such as particle size, Tc loading, stability in waste melters, and hazards of reagents for synthesis are important when considering each mineral form. Large-sized mineral particles will present less surface area-to-volume and relatively high 
stability, thus limiting the interaction between the melt and any incorporated Tc. Thus, particle size over a micrometer is preferable to sizes of mere nanometers. High Tc loading in the mineral reduces the material volume added to the waste-glass melter. A host phase with low solubility in glass may delay decomposition of the phase, allowing less volatility than a more soluble phase. High-cost or hazardous synthetic routes for candidate materials are also undesirable factors that must be considered in selecting candidates.

To be useful for carrying Tc into glass melt, the phase chosen must be stable at very high temperatures and able to withstand the conditions of boiling glass feed. To be easily integrated into WTP operations, there must be a way that is energetically inexpensive and safe in terms of radiation exposure to synthesize the Tc-carrying material. Finding the suitable host mineral phase and how to synthesize it in an ideal form for maximizing the retention of Tc within the melter has not yet been accomplished. The goal of the present paper is to summarize the synthetic routes for materials that may serve as Tc waste-forms. This will include methods to make these various materials without Tc, as many of the mineral synthesis techniques found in the literature do not pertain to studies where Tc incorporation was a goal. Some consideration is given to which waste forms are most easily applicable to vitrification as a final fate.

\section{Host Phases for Tc Incorporation}

Table 1 lists crystal structures discussed in this section including the theoretical Tc loading in each structure $[12,19,21,23,25,28-30]$. Each mineral and the techniques that have been demonstrated to synthesize them are described below in greater detail.

The presumed Tc redox state in oxic environments, including the Hanford tank waste, is $\mathrm{Tc}^{7+}\left(\mathrm{TcO}_{4}{ }^{-}\right)[31]$, although non-pertechnetate species also are known to exist [32]. Some 
minerals, such as sodalite, can incorporate the $\mathrm{Tc}$ in the $\mathrm{Tc}^{7+}$ state $[12,29]$. Because many minerals can only incorporate the tetravalent ion $\mathrm{Tc}^{4+}[26]$, the $\mathrm{Tc}$ must undergo a reduction to be incorporated in them. The redox of Tc couples with another species within the proximity of the $\mathrm{Tc}^{7+}$, such as divalent iron $\left(\mathrm{Fe}^{2+}\right)$ shown in Equation (1), could drive the reduction of $\mathrm{Tc}^{7+}$ to $\mathrm{Tc}^{4+}[22,28,33] . \mathrm{The}^{\mathrm{Tc}} \mathrm{c}^{4+}$ ion has a radius of $78.5 \mathrm{pm}$, which is identical to high-spin $\mathrm{Fe}^{3+}$, and very similar to $\mathrm{Ti}^{4+}$, which has a radius of $74.5 \mathrm{pm}$ [28]. Both $\mathrm{Fe}$ - and titanium-based minerals are therefore natural starting points in the search for a phase that can incorporate $\mathrm{Tc}^{4+}[28]$.

$$
\begin{gathered}
\mathrm{Tc}^{7+}+3 \mathrm{e}^{-} \rightarrow \mathrm{Tc}^{4+} \\
3 \mathrm{Fe}^{2+} \rightarrow 3 \mathrm{e}^{-}+3 \mathrm{Fe}^{3+}
\end{gathered}
$$

\subsection{Spinel}

Spinel is a mineral of the cubic space group $F d 3 m$ that can coordinate a wide variety of metal cations in either tetrahedral (A sub-lattice) or octahedral (B sub-lattice) sites [34, 35]. In all spinel, oxygen is arranged in a face-centered-cubic lattice, wherein these sites are situated. Two general types of spinel exist, normal spinel and inverse spinel. For a normal spinel, the general formula is $\mathrm{A}^{2+} \mathrm{B}_{2}^{3+} \mathrm{O}_{4}$ where $\mathrm{A}^{2+}$ and $\mathrm{B}^{3+}$ are $2+$ and $3+$ metal cations that occupy the tetrahedral and octahedral sites, respectively. In an inverse spinel, the general formula is the same $\left(\mathrm{A}^{2+} \mathrm{B}_{2}{ }^{3+} \mathrm{O}_{4}\right)$, but the $2+$ cations occupy octahedral sites and $3+$ cations are split between tetrahedral and octahedral sites. Common $\mathrm{A}^{2+}$ cations include $\mathrm{Mg}^{2+}, \mathrm{Ni}^{2+}, \mathrm{Fe}^{2+}$, and $\mathrm{Zn}^{2+}$, whereas the $\mathrm{B}^{3+}$ cations often include $\mathrm{Al}^{3+}, \mathrm{Fe}^{3+}$, and $\mathrm{Cr}^{3+}$. Spinel containing tetravalent cations, such as ulvöspinel, a type of normal spinel, contain a $4+$ metal cation instead of a $3+$ cation and has the general formula of $\mathrm{A}_{2}{ }^{2+} \mathrm{B}^{4+} \mathrm{O}_{4}$. In this case, the 4+ cation is in the octahedral site and the $2+$ cation is distributed between the octahedral and tetrahedral sites. A model of ulvö-type spine is shown in Figure 2. Here, the most common $\mathrm{B}^{4+}$ cation in the literature is $\mathrm{Ti}^{4+}$ and divalent 
cations including $\mathrm{Fe}$, magnesium, cobalt, manganese, nickel, and zinc (i.e., $\mathrm{Fe}^{2+}, \mathrm{Mg}^{2+}, \mathrm{Co}^{2+}$, $\mathrm{Mn}^{2+}, \mathrm{Ni}^{2+}$, and $\left.\mathrm{Zn}^{2+}\right)[34]$.

Magnetite, or $\mathrm{Fe}_{3} \mathrm{O}_{4}\left(\mathrm{Fe}^{2+} \mathrm{Fe}_{2}{ }^{3+} \mathrm{O}_{4}\right)$, is a type of inverse spinel often found in soil and sometimes proposed as a method to reduce pertechnetate to the less-mobile $\mathrm{Tc}^{4+}[36,37]$. The short-lived ${ }^{99 \mathrm{~m}} \mathrm{Tc}$ isotope has also been added to magnetite particles for use in medical imaging [38]. Magnetite is a special case of spinel because the $\mathrm{Fe}^{2+}$ often gets oxidized to $\mathrm{Fe}^{3+}$ in the melter, readily forming hematite $[39,40]$. While hematite has been predicted to be capable of including $\mathrm{Tc}^{4+}$ into its structure $[41,42]$, magnetite is not a particularly durable phase in melter conditions, allowing the Tc it bears to be oxidized [16]. In contrast, spinel such as $\mathrm{NiFe}_{2} \mathrm{O}_{4}$

(trevorite, $\mathrm{Ni}^{2+} \mathrm{Fe}_{2}{ }^{3+} \mathrm{O}_{4}$ ) or gamma- $\mathrm{Fe}_{2} \mathrm{O}_{3}$ (maghemite) can be much less redox sensitive because the only $\mathrm{Fe}^{2+}$ present will be from that needed to charge balance the $\mathrm{Tc}^{4+}$ introduced in the system, and the $\mathrm{Fe}^{3+}$ is not likely to undergo reduction at melter operating temperatures.

While many methods exist to make spinel, synthesis of Tc-bearing spinel is dominated by high-temperature methods first employed by Muller et al. [21]. Most research into Tc mixed oxides (spinel, pyrochlore, perovskite, rutile, etc.) has used high-temperature sintering to produce test materials $[18,21,43,44]$. Many papers describe a host of alternative routes to spinel; however, only a few have been demonstrated for making Tc spinel [28, 45].

Figure 3 shows scanning electron microscopy (SEM) and transmission electron microscopy (TEM) micrographs of spinel without Tc at various different sizes made by different synthesis techniques presented in the literature [46-49].

\subsubsection{High-Temperature Sintering}

Muller et al. [21] described many new forms of Tc-containing spinel, all achieved by heating oxides to circa $1200^{\circ} \mathrm{C}$. High-temperature syntheses of several phases were described 
and provided a foundation for subsequent Tc-mineral studies. The approach they used involved finely mixed oxides sintered under inert atmosphere in sealed platinum vessels at temperatures at or just above $1200^{\circ} \mathrm{C}$. Grinding the starting oxides in acetone or mixing with $20 \mathrm{~mol} \%$ of $2 \mathrm{NaCl}: \mathrm{NaF}$ used as a mineralizer increases the reactivity of oxides [50]. This method has been used with very little variation to study Tc-bearing phases [18, 21, 43, 44].

The high-temperature sintering has been shown to produce pure, micrometer-sized Tcbearing spinel of varied stoichiometry [21]. However, the challenges of high-temperature synthesis include engineering demands and the need to first reduce $\mathrm{Tc}$ from $\mathrm{Tc}^{7+}$ to $\mathrm{Tc}^{4+}$. Energy is needed to heat the samples, oxygen pressure must be controlled, and volatile Tc poses a risk if containment is compromised while at high temperature. The process also requires $\mathrm{TcO}_{2}$ as a reagent, which would have to be isolated and reduced from waste streams as a prerequisite to WTP application. This makes the synthesis a multi-step process and more imposing on the existing WTP flow sheet than a system that could incorporate the Tc directly from the waste stream.

The spinel forms described in the work by Muller et al. [21] included $\mathrm{A}_{2} \mathrm{TcO}_{4}$ spinel, where $\mathrm{A}=\mathrm{Mg}, \mathrm{Co}, \mathrm{Mn}, \mathrm{Zn}, \mathrm{Ni}$, and/or cadmium [21]. Pure products were reported in all cases except for $\mathrm{Co}_{2} \mathrm{TcO}_{4}, \mathrm{CoNiTcO}_{4}$, and $\mathrm{NiCdTcO}_{4}$, where impurities were detected with X-ray diffraction (XRD). Most of these have Ti-based analogues and many have been demonstrated as mixtures of $\mathrm{Tc}$ and $\mathrm{Ti}$. Solid solutions of Tc-Ti spinel have been demonstrated including a series of Ti-Tc-Mg spinel with both end members (i.e., $\mathrm{Mg}_{2} \mathrm{TcO}_{4}$ and $\left.\mathrm{Mg}_{2} \mathrm{TiO}_{4}\right)[18,43,51]$. Lattice parameters increase with the increasing degree of Tc substitution, and these data agreed with parameters for $\mathrm{Mg}_{2} \mathrm{TiO}_{4}$ and $\mathrm{Mg}_{2} \mathrm{TcO}_{4}$ set forth by Muller et al. [21]. It is noted that the syntheses of Tc phases occur at lower temperatures than the Ti analogues; this is thought to be 
due to the fluxing action of vaporous Tc at these temperatures, compared to the much lower vapor pressure of Ti.

Increasing the Tc loading of titanate spinel may be possible through a process that incorporates oxides into spinel lattices. Titanate spinel of the form $\mathrm{Zn}_{2} \mathrm{TiO}_{4}$ can be sintered with $\mathrm{TiO}_{2}$ to create a solid solution of up to $0.28 \mathrm{M} \mathrm{TiO}_{2}: \mathrm{Zn}_{2} \mathrm{TiO}_{4}$ of 0.28 [52]. This creates a singlephase product that has increased occupancy of $\mathrm{Ti}^{4+}$ into octahedral sites and $\mathrm{Zn}^{2+}$ vacancies in tetrahedral sites. The $\mathrm{TiO}_{2}$ is introduced as rutile and sintered at $950^{\circ} \mathrm{C}$ for this process. The $\mathrm{TcO}_{2}$ oxide possibly could combine with $\mathrm{Zn}_{2} \mathrm{TiO}_{4}$ spinel via an analogous method [53].

Unsuccessful syntheses also were reported, including $\mathrm{Cu}_{2} \mathrm{TcO}_{4}, \mathrm{Ni}_{2} \mathrm{TcO}_{4}, \mathrm{NiTc}_{2} \mathrm{O}_{4}$, $\mathrm{Fe}_{2} \mathrm{TcO}_{4}, \mathrm{FeTc}_{2} \mathrm{O}_{4}$, and $\mathrm{Zn}_{2} \mathrm{TcO}_{4}$ [21]. These were described as having little or no reaction at high temperatures, or breaches in the Pt foil at long reaction times, thus preventing synthesis. For a successful synthesis, the metal cations must be suited for the octahedral and tetrahedral sites in the structure. The $\mathrm{Tc}^{4+}$ ion has a strong preference for the octahedral site, so a divalent cation then needs to fill half of the octahedral sites and the part of the tetrahedral sites as well. To this end, a cation, such as Mg or Mn, with no particular affinity for either tetrahedral or octahedral sites should be chosen. This is the explanation given as to why the $\mathrm{Ni}_{2} \mathrm{TcO}_{4}$ end-member $(\mathrm{Ni}$ having a preference for octahedral sites) and $\mathrm{Zn}_{2} \mathrm{TcO}_{4}$ end members ( $\mathrm{Zn}$ having a tetrahedral preference) do not form by themselves, but a $\mathrm{NiZnTcO}_{4}$ will form readily [21].

Sintering oxides at pressures of GPa has been shown to create $\mathrm{MgFe}_{2} \mathrm{O}_{4}$ spinel with up to 0.35 mass $\%$ rhenium, [54]. Rhenium is a non-radioactive chemical surrogate for Tc, with similar volatility and chemical speciation $[6,36]$.This is meant to mimic the geological conditions that yield Re-bearing spinel, with concentrations on the order of fractions of $\sim 1 \mathrm{ng} \mathrm{Re} / \mathrm{g}$ of spinel $[55]$. 


\subsubsection{Aqueous Precipitation and Co-Precipitation}

Co-precipitation is a two-step reaction in which dissolved cations are mineralized into nuclei, where particle growth then occurs [40]. The basic procedural template involves combining divalent and trivalent metal salts in solution, and mineralizing with a strong base. The reaction is generally given in Equation (2) where $x>>8$ and M represents a divalent cation (e.g., $\mathrm{Ni}^{2+}$ or $\left.\mathrm{Fe}^{2+}\right)[56]$.

$(x \geq 8) \quad \mathrm{MCl}_{2}+2 \mathrm{FeCl}_{3}+x \mathrm{NaOH} \rightarrow \mathrm{MFe}_{2} \mathrm{O}_{4}+(x-8) \mathrm{NaOH}+4 \mathrm{H}_{2} \mathrm{O}+8 \mathrm{NaCl}$

Lukens et al. [28] demonstrated Tc incorporation into spinel with an aqueous

precipitation method. This method is performed at much lower temperatures than the procedure described by Muller et al. [21] $\left(90^{\circ} \mathrm{C}\right.$ instead of $\left.1200^{\circ} \mathrm{C}\right)$, and yields smaller product size (nanometer-sized instead of micrometer-sized) with lower Tc loading (4 mass $\%$ instead of 40 mass \%). The starting form of $\mathrm{Tc}_{\mathrm{c}}$ is $\mathrm{TcO}_{4}{ }^{-}$instead of $\mathrm{TcO}_{2}$, and a ferrite spinel is formed instead of titanate. Starting the reaction with an aqueous $\mathrm{TcO}_{4}{ }^{-}$ion is more congruent with the aqueous conditions of Hanford waste. $\mathrm{Ti}^{4+}$ incorporation into magnetite, which has been well characterized, suggests that $\mathrm{Tc}^{4+}$ may likewise incorporate into magnetite, given that $\mathrm{Ti}^{4+}$ and $\mathrm{Tc}^{4+}$ are similar in radius $(0.745$ and $0.785 \AA$, respectively) [37]. The lower reaction temperature reduces the process energy cost and removes concern for Tc volatility.

In the method by Lukens et al. [28], salts of $\mathrm{Fe}^{2+}$ and $\mathrm{Fe}^{3+}$, an additional divalent metal $\left(\mathrm{Ni}^{2+}, \mathrm{Mn}^{2+}, \mathrm{Mg}^{2+}\right.$, or $\left.\mathrm{Co}^{2+}\right)$, and $\mathrm{TcO}_{4}{ }^{-}$are dissolved in anoxic water. Then, $\mathrm{NaOH}$ is added to increase the $\mathrm{pH}$ and precipitate the metal ions. In this case, the reduction of $\mathrm{Tc}^{7+}$ to $\mathrm{Tc}^{4+}$ is driven by the oxidation of $\mathrm{Fe}^{2+}$ to $\mathrm{Fe}^{3+}$ through the redox couple presented above in Equation (1). The results of this process showed that 99 mass $\%$ of Tc is removed from solution by these methods, with spinel as the major product [28]. 
Analysis of spinel products by both methods used by Lukens et al. [28] shows crystal sizes ranging from 19 to $38 \mathrm{~nm}$ for the so-called oxidation method (mineralization in the presence of nitrate), and 9 to $24 \mathrm{~nm}$ for the so-called co-precipitation method (mineralization without nitrate). Extended X-ray absorption fine structure analysis was used to examine the ordering of Tc in the structure, and showed high Tc clustering for the magnetite and ferrites other than $\mathrm{Tc}_{0.1} \mathrm{Ni}_{1.1} \mathrm{Fe}_{1.8} \mathrm{O}_{4}$ (trevorite). This high clustering suggests that a separate Tc phase could be occurring in cases other than for trevorite.

To date, the method from Lukens et al. [28] is the only aqueous precipitation approach to produce Tc-bearing pure trevorite spinel. However, other methods are described here for making spinel from solution, and most do not include Tc. Many of these methods involve precipitating intimate mixtures of oxides or other spinel precursors, followed by sintering to crystalize the product. Other procedures produced spinel directly, without further heating. A discussion of these procedures follows in Section Error! Reference source not found..

Tc-bearing magnetite is co-precipitated from a solution with $\mathrm{pH}$ ranging from 12.5 to 13.1 when $\mathrm{Fe}^{2+}$ cations (from $\mathrm{FeCl}_{2}$ ) and $\mathrm{TcO}_{4}{ }^{-}$(from $\mathrm{NH}_{4} \mathrm{TcO}_{4}$ ) are added in the presence of ferrihydrite [36]. The $\mathrm{Fe}^{2+}$ deposits on the ferrihydrite nano-particles at high $\mathrm{pH}$ and reduces the $\mathrm{Tc}^{7+}$ to $\mathrm{Tc}^{4+}$ as a result of heterogeneous surface-catalyzed reduction, which fills octahedral sites as the formation of magnetite occurs and particles grow. A Tc content of $\sim 500 \mathrm{ppm}$ in magnetite was achieved from a starting solution of $\sim 30 \mu \mathrm{M} \mathrm{NH}_{4} \mathrm{TcO}_{4}$. While Tc was totally removed from solution by this method, 20 to $60 \%$ was released back into solution when exposed to oxidative conditions. This leaching was found to remove Tc from an outer layer of the magnetite nanoparticles, which was oxidized into goethite. Leaching was apparently arrested after the initial goethite-forming oxidation, even after several months under oxidative conditions [36]. 
Unfortunately for our purposes, nanometer-sized particles have received most of the attention in the literature because of interest in their use in batteries and conductors. Small particle sizes allow for easier diffusion of Tc from the lattice, re-oxidation, and Tc release [57]. To some extent, nano-particles can be armored with an amorphous silica layer, that may mitigate Tc diffusion by coating nano-particles during a second precipitation step after the initial particles form [58].

Salts used for precipitation of spinel without Tc including nitrates [59], sulfates [60], and organic ligands [40, 50]. Commonly used bases include $\mathrm{NaOH}$ [56], $\mathrm{KOH}$ [60], and $\mathrm{NH}_{4} \mathrm{OH}$ [61]. Divalent metal salts can include $\mathrm{Zn}^{2+}[62], \mathrm{Mn}^{2+}[56], \mathrm{Co}^{2+}[63], \mathrm{Fe}^{2+}[64]$, and $\mathrm{Ni}^{2+}[65]$, although others have been demonstrated. Co-precipitation and subsequent heat treatment can produce micrometer-sized spinel several hundred degrees lower than the simple sintering of oxides [66].

In cases of redox sensitivity, such as the synthesis of magnetite, anoxic water must be used to prevent over-oxidation due to $\mathrm{O}_{2}$. One study achieved a pure product without the need to control atmosphere, using ambient $\mathrm{O}_{2}$ as an oxidizing agent and adjusting starting concentrations of $\mathrm{Fe}^{2+}$ and $\mathrm{Fe}^{3+}$ [64].

In the case of magnetite synthesis, $\mathrm{NH}_{4} \mathrm{OH}$ was found to be superior to alkali hydroxides, where a cation concentration of $0.1 \mathrm{M}$, a temperature of $45^{\circ} \mathrm{C}$, and mixing of the cation solution into the basic solution was found to be ideal $[60,61,67]$.

Many products require sintering to 300 to $900^{\circ} \mathrm{C}$ to promote crystallinity, but aging with urea at $90^{\circ} \mathrm{C}$ or heating in boiling water for several hours can yield nanometer-sized products without further sintering $[56,62]$. 


\subsubsection{Micro-Emulsion Synthesis}

Micro-emulsion is a form of co-precipitation in which particle growth is inhibited because the reacting solution is contained in discrete bubbles within an organic liquid. This is a common technique and is used to limit the amount of reagents that can interact, thereby limiting the potential particle size. While limiting particle size is not an aim of synthesizing a Tc host phase, much of the literature is dedicated to creating nanometer-sized particles. Furthermore, most emulsion methods often require sintering of the product to promote crystallinity $[50,58,59$, 68-70], which the method by Lukens et al. [28] avoids.

A survey by Calbo et al. [50] of unconventional trevorite syntheses compares microemulsion to other methods, showing that it produces more crystalline product at lower temperatures than conventional sintering, but its performance is inferior to co-precipitation. In a typical technique, an aqueous solution of $\mathrm{NiCl}_{2}$ and $\mathrm{FeCl}_{3}$ is mixed in a 1:5 molar ratio with isooctane and two surfactants, and treated ultrasonically. A second micro-emulsion of ammonia is then prepared, and mixed with the first emulsion. After an hour of ultrasonic mixing, a product layer can be isolated, dried, and fired at 800 or $1000^{\circ} \mathrm{C}$ [50]. Ricin oil and $\mathrm{NaOH}$ [68] or methylamine [70] can be used in place of octane and ammonia, and organics such as cyclohexane [69] or toluene [59] in water also can be used to create an emulsion. Particle size is often less than $10 \mathrm{~nm}$.

\subsubsection{Sol-Gel Synthesis}

While co-precipitation nucleates spinel in solution, other aqueous methods can tend to precipitate an amorphous product that can be calcined into spinel, albeit at lower temperatures than would be necessary with conventional sintering. Sol-gel processes condense precursor materials in a 'gel' through polycondensation reactions that form a network of nanometer-sized 
particles when calcined. The sol-gel method allows the precursors to be intimately mixed and crystallize into spinel at a lower temperature. Spinel synthesized using such a scheme yield 5150 nanometer-sized particles.

Synthesis of spinel by a sol-gel method can be done with various metal salts and solvents. Nickel and ferric nitrates in a gel of ethylene glycol are used to synthesize trevorite [71]. Acetonates of nickel and iron also can be dissolved in ethanol, then combines with nitric acid and acetylacetone to the same effect [50]. Nitrates of metals in aloe vera extract have even been shown to create a sol [48]. All three of these approaches require sintering of products after the sol is dried. Particle size of the product depended strongly on the sintering temperature [72]. While this method does operate at lower temperatures than those described by Muller et al. [21], heating is required to produce crystallized 5-150 nanometer-sized spinel. This process remains untested in regards to Tc compatibility.

\subsubsection{High-Temperature Reflux}

Another approach to spinel synthesis is refluxing organometallic reagents in liquids with high boiling points. During reflux, a solvent is heated in a vessel near its boiling point and allowed to continuously condense and flow back into the vessel. Synthesizing nanometer-sized spinel crystals in a high-temperature reflux over $100^{\circ} \mathrm{C}$ takes advantage of the heat refluxing the solvent and the relative instability of the metal complexes as compared to the spinel form.

Various related methods are described in the literature. Cobalt and iron acetates have been reacted at $260^{\circ} \mathrm{C}$ to reflux in phenyl ether and hexadecanediol for 30 minutes, and then precipitated spinel when ethanol was added [73-75]. Alternately, metal acetylacetonates can be thermally decomposed in olymine at $220^{\circ} \mathrm{C}$ [76]. In a series of papers, Song et al. [73-75] described a seed-mediated growth that used smaller products of the refluxing as a seed for crystal 
growth in a subsequent round of reactions. In a seed-mediated reaction, 12-nm crystals were grown from 4-nm precursors. The third report (Song et al. [75]) describes using seeds of one composition with a reflux batch of another composition to create core-shell nano-particles, such as 6-nm $\mathrm{CoFe}_{2} \mathrm{O}_{4}$ crystals with a 1-nm shell of $\mathrm{MnFe}_{2} \mathrm{O}_{4}$ [75]. Seeding also was shown to increase crystallinity for several other precursor-preparation methods, besides high-temperature reflux [77].

\subsubsection{Hydrothermal Syntheses}

Hydrothermal methods use sealed pressure vessels to obtain above-boiling temperatures and pressures for aqueous reactions [71]. If an increase in either pressure or temperature leads to an increase in grain growth, particle sizes can be increased. Hydrothermal syntheses methods have achieved the largest spinel achieved by aqueous methods (larger than $1 \mu \mathrm{m}$ ) [46]. No literature examined hydrothermal methods with Tc chemistry, but extant aqueous methods with Tc may be adapted to hydrothermal synthesis.

In a straight-forward method, $\mathrm{CoCl}_{2}$ and $\mathrm{FeCl}_{3}$ were reacted in $2 \mathrm{M} \mathrm{NaOH}$ solution. Next, hydrothermal treatment was performed at $130^{\circ} \mathrm{C}$ [78]. Alternately, iron citrate and zinc and manganese acetates are dissolved in a $50 \% \mathrm{NH}_{3}$ solution and autoclaved to over $130^{\circ} \mathrm{C}$ [79]. While these methods produced spinel that were only tens of nanometers in size, larger sizes are possible. For example, in a hydrothermally assisted micro-emulsion, $\mathrm{Ni}\left(\mathrm{NO}_{3}\right)_{2}$ and $\mathrm{Fe}\left(\mathrm{NO}_{3}\right)_{3}$ nitrates, polyoxyethylene(10)nonylphenyl ether, and hexane can be added together, followed by addition of cetyltrimethylammonium bromide, iso-amyl alcohol, and urea and an autoclave heat treatment for 30 hours, producing 100-nm crystals [80]. Additionally, 200-nm crystals were synthesized when $\mathrm{Zn}(\mathrm{OAc})_{2}$ and $\mathrm{FeSO}_{4}$ were dissolved in water with stirring, hydrazine was added, and the solution was autoclaved at $180^{\circ} \mathrm{C}$ for 14 hours [81]. Various other starting 
materials have included $\mathrm{Ni}(\mathrm{OH})_{2}, \mathrm{FeO}(\mathrm{OH})$ (goethite), and $\mathrm{Fe}_{2} \mathrm{O}_{3}$ autoclaved in the presence of $\mathrm{NaCl}$. Use of different reagents demonstrated that different morphologies of products can be produced, with goethite proving more reactive and producing more crystalline products than $\mathrm{Fe}_{2} \mathrm{O}_{3}[82]$. The largest sized spinel product was obtained from goethite and amorphous $\mathrm{NiO}$ from a $\mathrm{Ni}\left(\mathrm{NO}_{3}\right)_{2}$ precipitation, which was hydrothermally treated at 180 to $200^{\circ} \mathrm{C}$ with $2 \mathrm{M}$ $\mathrm{NaOH}$ [46]. These achieve sizes of $>1 \mu \mathrm{m}$ for single crystals — a notably large size for trevorite produced from aqueous synthesis. Goethite and amorphous $\mathrm{NiO}$, which are less thermodynamically stable than well crystalline oxides, were intended to be more reactive phases than $\mathrm{Fe}_{2} \mathrm{O}_{3}$ or well-crystallized NiO. This is thought to be a contributor to the large particle sizes obtained in that study.

Kuznetsova et al. [78] examined the effects of ultrasonic treatment of solutions before heating with and without a microwave heat source. Microwave heating led to product in less time than conventional heating, and ultrasonic pre-treatment increased the performance of microwave

heating even more. These experiments also showed that ultrasonic treatment was only effective if it preceded hydrothermal heating by $<2$ hours. These effects may be useful for increasing the kinetics of methods that show promise, such as the Chen [46] method.

\subsubsection{Liquid Nitrogen-Assisted Synthesis}

In what must be considered a unique approach, Jang achieved 100-nm sized particles of $\mathrm{CoMn}_{2} \mathrm{O}_{4}$ below room temperature [63]. By promoting the autoxidation of $\mathrm{Mn}_{3} \mathrm{O}_{4}$ from $\mathrm{Mn}\left(\mathrm{NO}_{3}\right)_{3}$ and $\mathrm{Mn}(\mathrm{OH})_{2}$, the reaction proceeded from the addition of dilute $\mathrm{Co}\left(\mathrm{NO}_{3}\right)_{2}$ and $\mathrm{Mn}\left(\mathrm{NO}_{3}\right)_{3}$ to $\mathrm{LiOH}$ at $\mathrm{pH} 11$. The solution was stirred in air for 12 hours before being rinsed, atomized into liquid nitrogen, and freeze-dried. A nearly pure 100-nm-sized product of $\left(\mathrm{Co}_{0.75} \mathrm{Mn}_{0.25}\right)_{3} \mathrm{O}_{4}$ was obtained. The same reaction yielded spinel when carried out with only 
$\mathrm{Mn}\left(\mathrm{NO}_{3}\right)_{3}$ in the absence of $\mathrm{Co}$, but not with $\mathrm{Co}\left(\mathrm{NO}_{3}\right)_{2}$ in the absence of $\mathrm{Mn}$, which only formed $\mathrm{Co}^{2+}$ and $\mathrm{Co}^{3+}$ hydroxides. The low-temperature atomization and control of $\mathrm{Mn}^{2+} / \mathrm{Mn}^{3+}$ redox is what allowed for spinel formation. Because Fe also forms divalent and trivalent ions, ferrites might be produced by a similar reaction using Fe instead of Mn. This could possibly lead to another low-temperature method to make Tc-bearing phases like trevorite.

\subsubsection{Ignition Synthesis}

Alarifi et al. [83] reported the synthesis of trevorite by combining $\mathrm{Ni}\left(\mathrm{NO}_{3}\right)_{2}$ and $\mathrm{Fe}\left(\mathrm{NO}_{3}\right)_{3}$ with glycine, which was heated to ignition. The chemicals were mixed in a porcelain crucible, which was heated until a fluffy black powder was formed from a sudden onset of sparks. The particles formed are approximately 4 to $67 \mathrm{~nm}$. Because Tc is easily oxidized to $\mathrm{Tc}^{7+}$ in air, it would likely not incorporate into the spinel lattice under these conditions, making ignition unlikely to be useful for Tc incorporation, but was included here for completeness.

\subsubsection{Molten Salt Synthesis}

Molten salt synthesis is a well-known industrial process that makes use of a liquid salt flux to dissolve (even if only partially) oxides at low temperatures [84]. When using liquid salt, the mobility of oxides is increased compared to high-temperature sintering, and reactions similar to high-temperature sintering can occur faster and at lower temperatures [85]. Factors such as the basicity of the salt melt, the temperature, and the speciation of the reagents can all affect the product composition, size, and reaction kinetics [86]. Compared with high-temperature sintering, the molten salt synthesis technique generally provides a more homogeneous product (as material transport in the reaction is increased), decreased agglomerations (as the salt flux coats the particles and inhibits necking), and at lower reaction temperatures (as much as $\leq 500^{\circ} \mathrm{C}$ ) [84]. It is a flexible technique, but has never been successfully adapted for Tc-spinel synthesis. 
In a typical synthesis, $\mathrm{NiO}$ and $\mathrm{Fe}_{2} \mathrm{O}_{3}$ are combined with $\mathrm{NaCl}$ and $\mathrm{KCl}$ [85]. Spinel forms and precipitates out of the salt flux upon heating to $900^{\circ} \mathrm{C}$ for 0.5 to 3 hours. Particle sizes resulting from this type of experiment are generally on the order of 0.1 to $10 \mu \mathrm{m}$ [87]. When $\mathrm{LiCl}$ and $\mathrm{KCl}$ are used as a low-melting flux, the lowest temperature needed for near-complete reaction of $\mathrm{NiO}$ and $\mathrm{Fe}_{2} \mathrm{O}_{3}$ into trevorite is $350^{\circ} \mathrm{C}$, [88]. This flux was heated to several temperatures and held for up to 6 months to achieve reaction. All treatments at $<1000^{\circ} \mathrm{C}$ yielded some unreacted oxides.

Salts can be used instead of oxides. For example, $\mathrm{Ni}\left(\mathrm{SO}_{4}\right)$ and $\mathrm{Fe}\left(\mathrm{NO}_{3}\right)_{3}$ were mixed with $\mathrm{NaOH}$ and $\mathrm{NaCl}$ and heated to $700^{\circ} \mathrm{C}$ [89]. The salt component and intimate combination of reagents through mixing allowed the resultant spinel to form at slightly lower temperatures than would be the case for mixing of larger grain oxides. After firing at $700^{\circ} \mathrm{C}$ for 1 hour, the resulting spinel grew to $\sim 10 \mathrm{~nm}$, which was unusually small for molten salt synthesis.

Template growth is one approach for molten salt synthesis in which a less-soluble, specifically shaped reactant is coated and reacted with a more soluble reactant [90]. This is demonstrated in several ways with molten salt synthesis and a tailored product shape can be created if less soluble reactants can be used. Preferred growth of crystal facets also is possible because the augmented mobility of reactants allows for selective placement of precipitating material onto energetically favorable edges. Using this approach, rod-shaped $\mathrm{NiFe}_{2} \mathrm{O}_{4}$ was prepared from molten chlorides by Hayashi, starting from acicular $\mathrm{Fe}_{2} \mathrm{O}_{3}$ [91]. Also, hexagonal plates of $\mathrm{NiO}$ crystals can be made and used in template growth [92]. Template-growth molten salt synthesis using this phase of $\mathrm{NiO}$ as a reagent could provide an energetically favorable and easily characterized $\mathrm{NiFe}_{2} \mathrm{O}_{4}$ product. If this type of spinel were added to a waste glass melt, the 
distinct hexagonal shape of the thus-formed spinel would be helpful in showing signs of reaction in a glass melt, as it would be distinguishable from in-grown octahedrally shaped spinel.

Even when salt fluxes are minor components, they can play a role in promoting ordering of oxides into spinel. In the study of trevorite syntheses by Calbo et al. [50], products were sintered both with and without the presence of $20 \mathrm{NaCl}: \mathrm{NaF}$. The presence of the salt did reduce impurities in one of the final sintered products [50].

In work by the current authors [47], $\mathrm{ReO}_{2}, \mathrm{~K}_{2} \mathrm{ReCl}_{6}$, and $\mathrm{TcO}_{2}$ were added to vacuumsealed ampoules of $\mathrm{Fe}_{2} \mathrm{O}_{3}, \mathrm{NiO}_{2}$, and chloride salts. After heating to $900^{\circ} \mathrm{C}, \mathrm{Re}^{4+}$ was shown to have oxidized to $\mathrm{ReO}_{3}$, and the Tc formed a non-spinel complex with $\mathrm{Fe}^{2+}$, likely bound to the surface of the trevorite that did form.

\subsubsection{Ball-Mill-Assisted Synthesis}

Because both heat and redox chemistry are complications for syntheses involving the volatile and easily oxidized Tc, a method without either heat or redox active reagent requirements is attractive. Ball-milling fits this description as starting materials, chiefly oxides, are homogenized and smashed in a ball mill for several hours, eventually leading to agglomerations of pure spinel product. Separated and reduced Tc would be required for this synthesis. The dispersal hazards of fine-grained oxides being violently impacted by milling media is unique to this method, and would require special consideration for Tc.

In one example, $\mathrm{Fe}_{2} \mathrm{O}_{3}$ powders coupled with either $\mathrm{NiO}$ or $\mathrm{ZnO}$ were milled at $10 \mathrm{G}$ acceleration with steel or corundum media to synthesize spinel nano-particles [93, 94]. The reaction was complete at 35 hours. The internal temperature of the mill reached $150^{\circ} \mathrm{C}$, due to the mechanical energy. Based on XRD peak widths, the crystallite size was estimated to be 6-nm. When corundum was used as the milling media, it was detected by XRD in the product. 
Similar results were reported when a planetary mill was used to combine $\mathrm{NiO}$ and $\mathrm{Fe}_{2} \mathrm{O}_{3}$; the rate of formation of spinel decreased after 11 hours of ball-milling, and resulted in 5-nm spinel [49].

In another example, low-energy milling completed formation $\mathrm{MgAl}_{2} \mathrm{O}_{4}$ after 160 hours [95]. Domanski et al. [95] compared $\mathrm{Al}_{2} \mathrm{O}_{3}, \gamma-\mathrm{Al}_{2} \mathrm{O}_{3}$ (transition alumina), and $\mathrm{AlO}(\mathrm{OH})$ and found that the $\gamma-\mathrm{Al}_{2} \mathrm{O}_{3}$ was much more reactive than either of the two other sources. Taking advantage of more reactive phases of reagents to boost product crystallinity in this study is comparable to the positive results seen in Chen et al. [46], and again highlights the usefulness of more reactive reagents in producing higher purity products in less time. On a related note, shortterm, low-energy milling required subsequent heating to $1000^{\circ} \mathrm{C}$ to observe formations of $\mathrm{MgAl}_{2} \mathrm{O}_{4}$ [96]. In this work, grinding was done in corundum media at 600 revolutions per minute, yielding significant corundum contamination after 110 minutes.

\subsection{Sodalite}

Sodalite is a crystal of the cubic space group 43 composed of 4- and 6-membered rings with the general formula of A8IBIIICIVO46D , where $\mathrm{A}^{+}, \mathrm{B}^{3+}$, and $\mathrm{C}^{4+}$ are generally $1+$ (and sometimes 2+), 3+, and 4+ cations and D can be $n$ moles of a variety of different 1- (e.g., $\left.\mathrm{Cl}^{-}, \mathrm{OH}^{-}, \mathrm{ReO}_{4}^{-}, \mathrm{TcO}_{4}^{-} ; n=2\right)[12,29,97-100]$ or 2- $\left(\mathrm{SO}_{4}{ }^{2-} ; n=1\right)$ [101] anions or $\mathrm{H}_{2} \mathrm{O}$ [102]. The structure of the $\mathrm{TcO}_{4}{ }^{-}$-containing sodalite is presented in Figure 5. Because sodalite can be formulated to contain either $\mathrm{TcO}_{4}{ }^{-}$or its analogue of $\mathrm{ReO}_{4}{ }^{-}$, this makes study of this mineral in non-radioactive scenarios a possibility. A wide range of methods can be used to synthesize sodalite; however, the one demonstrated for making sodalite with the $\mathrm{TcO}_{4}{ }^{-}[12]$ and $\mathrm{ReO}_{4}{ }^{-}[29$, 99] oxyanions is a low-temperature hydrothermal method [12, 29].

In efforts to characterize steam bed reformers, $\mathrm{TcO}_{4}{ }^{-}$- and $\mathrm{ReO}_{4}{ }^{-}$-bearing sodalite was synthesized by Missimer et al. [12] (Figure 6a). They combined $6 \mathrm{~g}$ of $\mathrm{NaReO}_{4}$ with $0.6 \mathrm{~g}$ of 
zeolite $4 \mathrm{~A}$, water, and $\mathrm{NaOH}$ in a pressure vessel and heated the mixture to $225^{\circ} \mathrm{C}$ for 7 days, at which time approximately $1.5 \mathrm{~g}$ of perrhenate sodalite was collected by filtration. For pertechnetate sodalite, $\sim 0.33 \mathrm{~g}$ of $\mathrm{NaReO}_{4}$ was replaced with $\mathrm{NaTcO}_{4}$, and the heat treatment was extended to 8 days. The structures and presence of Tc in the pertechnetate sodalite were confirmed by XRD and EDS, respectively. The Tc-loaded sodalite contained Re and Tc, but elemental analysis was not done to determine an exact ratio.

Mattigod et al. [29] produced $\mathrm{ReO}_{4}{ }^{-}$-sodalite through hydrothermal processing at $175^{\circ} \mathrm{C}$ for 1 day (Figure 6b). Dickson et al. report making a perrhenate/nitrate [99] sodalite by combining $\mathrm{NaReO}_{4}$ with zeolite $\mathrm{A}$ and $\mathrm{NaOH}$ and heating to $90^{\circ} \mathrm{C}$. Their XRD analysis appeared to show the Re product was pure.

\subsection{Rutile}

Rutile is of the tetragonal space group $P 4 / m n m$ and is nominally an allotrope of $\mathrm{TiO}_{2}$. The structure of this mineral is shown in Figure 7 with a theoretical replacement of Ti with Tc. This crystal structure can incorporate diverse formulae of Ti, V, Nb, Ta, Mo, Re, and other metals [103]. Rutile is a fairly inert structure that may prove a useful candidate host phase for Tc. Rutile is compositionally $\mathrm{TiO}_{2}$, and has been shown to incorporate $\mathrm{Tc}$ in high-temperature syntheses [21].

Muller et al. [21] first showed that $\mathrm{TcO}_{2}$ could be sintered with anatase $\mathrm{TiO}_{2}$ to form a Tc-rutile. Anatase transitions to rutile when heated, and $\mathrm{TcO}_{2}$ will join the rutile structure if present. This was done in the same manner as the other high-temperature syntheses by mixing oxides in Pt crucibles and heating to $>1000^{\circ} \mathrm{C}$. A more recent study [104] reported on the synthesis of $\mathrm{Tc}_{0.1} \mathrm{Ti}_{0.9} \mathrm{O}_{2}$, with $\mathrm{Tc}$ starting as $\mathrm{NH}_{4} \mathrm{TcO}_{4}$, and mixed with $\mathrm{TiO}_{2}$ (anatase) powder. While samples sintered to $1300^{\circ} \mathrm{C}$ in flowing argon successfully incorporated Tc into the rutile 
phase, Tc reduction to metal was seen at higher temperature. Off-gassing of $\mathrm{O}_{2}$ from Tc reduction caused fissuring of the samples and a Tc-deficient layer in the sample. Stewart et al. [104] noted that the loss from rutile is greater than from Tc-perovskite phase exposed to the same heating conditions, and suggested that migration of Tc in the perovskite phase is inhibited compared to that of the rutile phase.

Full conversion of anatase-to-rutile within 1 hour is achieved at $120^{\circ} \mathrm{C}$ lower when porous, nanometer-sized particles, a mildly reducing atmosphere, and additives such as $\mathrm{Fe}_{2} \mathrm{O}_{3}$ are used. This indicates that it is possible to lower the incorporation temperature of $\mathrm{Tc}$ into rutile from what had been originally reported by Muller et al. [21]. Particle size can be modified with additions to sintering reagents. In particular, the addition of $1 \mathrm{~mol} \%$ of $\mathrm{Fe}_{2} \mathrm{O}_{3}$ or $\mathrm{MoO}_{3}$ increased the grain size of rutile formed at $800^{\circ} \mathrm{C}$ fivefold, to $>2 \mu \mathrm{m}$ [105]. The addition of $\mathrm{Fe}_{2} \mathrm{O}_{3}$ is shown to catalyze the anatase-to-rutile transition [106], which is the reaction demonstrated by Muller et al. [21] to incorporate Tc into rutile. Reducing atmospheres and electrical fields also increase reaction rates and particle sizes [107-110].

Preparation of porous, nanometer-sized anatase particles can be accomplished by the solgel method of polyalkylene oxide and tetrabutyl orthotitanate. Precipitating this product with other oxides would create a more intimate mixture of anatase and any additives deemed necessary to promote the anatase-to-rutile conversions [111]. This method would be a promising route for preparing readily reactive anatase mixtures, and lower temperature rutile-forming methods.

Rutile and other phases can be formed by self-propagating, high-temperature synthesis $[112,113]$. Highly reactive redox pairs such as metallic Ti or zirconium $(\mathrm{Zr})$ and oxides such as $\mathrm{MoO}_{3}, \mathrm{Fe}_{2} \mathrm{O}_{3}$, or $\mathrm{Tc}_{2} \mathrm{O}_{7}$ are combined and ignited, creating a multiphase product. The metals act 
as redox couples and exchange oxidation states in extremely quick and exothermic reactions, yielding pyrochlore, perovskite, rutile, or even alloys. The redox of the reaction and the extent of oxidation of the final products can be controlled by the ratio of starting materials. Molybdenum was used by Laverov et al. [114] as a surrogate for Tc, and rutile phases formed by selfpropagating, high-temperature synthesis are found to contain the most Mo, followed by perovskite, then pyrochlore.

The high temperatures that these reactions occur at obviously present a challenge to Tc applications because of the volatility of Tc.

\subsection{Tin Oxide}

Sintered $\mathrm{SnO}_{2}$ doped with $\mathrm{Sb}^{3+}$ and $\mathrm{Sb}^{5+}$ share the tetragonal space group $P 4_{2} / m n m$ with rutile [115]. This mixed oxide is able to selectively reductively eliminate $\mathrm{TcO}_{4}{ }^{-}$out of solutions,

reducing it to $\mathrm{Tc}^{4+}$ during the process [30]. This is not an ionic exchange; rather, an incorporation of Tc into lattice vacancies occurs even in the presence of competing ions such as $\mathrm{Cl}^{-}, \mathrm{NO}_{3}{ }^{-}$, $\mathrm{Ca}^{2+}$, and $\mathrm{NH}_{4}^{+}$[116]. The Tc-doped $\mathrm{SnO}_{2}$ has been shown to be a suitable host phase for Tc, It has high chemical durability and can be heated in air without loss of Tc [117].

These properties combined indicate that $\mathrm{SnO}_{2}$ may be a suitable material to remove Tc from the melter off-gas or other waste streams. Achieving both these objectives with one material and without additional chemical separation or processing of Tc would be minimally disruptive to current WTP processes. Further testing of Tc removal into $\mathrm{SnO}_{2}$ from off-gas simulants and durability in glass melts are needed to more fully evaluate this material as a viable candidate material. 


\subsection{Pyrochlore}

Pyrochlore is from the cubic space group $F d-3 m$ and has a general formula of either $\mathrm{A}_{2} \mathrm{~B}_{2} \mathrm{O}_{6}$ or $\mathrm{A}_{2} \mathrm{~B}_{2} \mathrm{O}_{7}$, where the $\mathrm{A}$ and $\mathrm{B}$ are most often rare earth or transition metals [118]. An example of a pyrochlore structure is presented in Figure 8. Pyrochlore has been examined as a waste form for actinides, and may be synthesized through diverse routes such as sintering, hydrothermal processes, and ball-milling. As discussed in Laverov et el. [112], self-propagating. high-temperature synthesis can form pyrochlore as a product phase. Pyrochlore also can incorporate technetium, and shows lower leach rates than waste glasses [112]. Several hightemperature syntheses methods have been designed for Tc-bearing pyrochlore.

In a procedure similar to that taken by Muller et al. [21], pyrochlore phases for $\mathrm{Tc}^{4+}$ and a number of lanthanides were achieved by sintering oxides in vacuum at $1150^{\circ} \mathrm{C}$ [19]. For $\mathrm{Pr}, \mathrm{Nd}$, Sm, and Gd unreacted reagents were 1 to 5\%. The particle size was calculated to be $120 \mathrm{~nm}$ [20]. Lower temperatures of pyrochlore formation were achieved when $\mathrm{TcO}_{2}$ and either $\mathrm{Bi}_{2} \mathrm{O}_{3}$ or $\mathrm{PbO}$ were combined in a mortar and pestle in methanol and heated to $700^{\circ} \mathrm{C}$ under $\operatorname{Ar}$ [4]. The challenges of the aforementioned high-temperature synthesis procedures apply to this approach, namely risk of technetium volatility, the need for pure and reduced reagents, and the engineering demands and modifications to WTP.

Rodriguez [4] used $\mathrm{Tc}_{2} \mathrm{O}_{7}$ to synthesize $\mathrm{Cd}_{2} \mathrm{Tc}_{2} \mathrm{O}_{7}$. Here, $\mathrm{Tc}_{2} \mathrm{O}_{7}$ and metallic Cd were sintered under vacuum at $800^{\circ} \mathrm{C}$, giving, to the authors' knowledge, the only reported synthesis of a Tc mixed oxide using $\mathrm{Tc}^{7+}$ as a reagent. While using $\mathrm{Tc}$ of the same oxidation state as is found in LAW $\left(\mathrm{Tc}^{7+}\right)$, this method is noted as being dependent on the absence of any water, which would pose limitations if adapted for use in the WTP. 
When the $\mathrm{Bi}_{2} \mathrm{Tc}_{2} \mathrm{O}_{7}$ product was combined with $\mathrm{Bi}_{2} \mathrm{O}_{3}$ and heated to $450^{\circ} \mathrm{C}$ under $\mathrm{O}_{2}$, $\mathrm{Bi}_{3} \mathrm{TcO}_{8}$ was synthesized. This phase is an analogue to $\mathrm{Bi}_{3} \mathrm{ReO}_{8}$, which has a melting point of $1473^{\circ} \mathrm{C}$ because of the ionic nature and fluorite structure, giving it high lattice energy. According to X-ray absorption near edge structure analysis, both $\mathrm{Tc}^{4+}$ and $\mathrm{Tc}^{7+}$ were present in $\mathrm{Bi}_{3} \mathrm{TcO}_{8}$ [4].

Re-bearing pyrochlore can also be synthesized by combining $\mathrm{ReO}_{3}$ and $\mathrm{CdO}$ under vacuum in a fused silica ampoule at $1000^{\circ} \mathrm{C}$ [119]. The Re and $\mathrm{Cd}$ oxidized, volatilized, and condensed on cooler, upper parts of the ampoule, forming millimeter-sized crystals. It is possible that this process could be extrapolated from Re precursors to Tc precursors.

At much lower temperatures and without Tc, the hydrothermal method used in Zeng et al. [120] offers a more energetically favored route to produce nano-particle pyrochlore. Here, $\mathrm{La}\left(\mathrm{NO}_{3}\right)_{3}$ and $\mathrm{SnCl}_{4}$ were dissolved in a high $\mathrm{pH}$ aqueous solution. A white precipitate that immediately formed was autoclaved at $200^{\circ} \mathrm{C}$ for $12 \mathrm{~h}$, which led to $\mathrm{La}_{2} \mathrm{Sn}_{2} \mathrm{O}_{7}$ nano-cubes of $\sim 60$-nm per side. This technique may be an applicable for making Tc-doped pyrochlore at low temperatures.

Fuentes et al. [121] used ball-milling to synthesize a distorted pyrochlore structure from $\mathrm{Y}_{2} \mathrm{O}_{3}, \mathrm{Gd}_{2} \mathrm{O}_{3}, \mathrm{Dy}_{2} \mathrm{O}_{3}$, and $\mathrm{TiO}_{2}$. Subsequent heating rearranged the oxygen lattice sufficiently to allow a fully ordered pyrochlore to form, and the temperature needed to induce this rearrangement decreased with increasing mill times $\left(806^{\circ} \mathrm{C}\right.$ for 9 hours milled, $744^{\circ} \mathrm{C}$ for 19 hours milled). This is similar to other ball-milling techniques to mechano-chemically combine oxides, followed by heating to further crystalize the material. Particle sizes were several nanometers in diameter. Milling was done in zirconia vessel and with zirconia media, and milling time ranged from 1 to 19 hours. Contamination of zircon in samples was $\leq 4 \%$, and rotational speeds were 350 revolutions per minute. 


\subsection{Perovskite}

Perovskite is a mineral phase of the orthorhombic space group Pnma with the formula $\mathrm{A}^{2+} \mathrm{B}^{4+} \mathrm{O}_{3}$, where $\mathrm{A}$ is a $2+$ cation and $\mathrm{B}$ is a $4+$ cation. A model of a perovskite is shown in Figure 9. In the literature, reports of Tc-containing perovskites are common, and Muller et al. [21] demonstrated $\mathrm{SrTcO}_{3}$ with a very slightly distorted perovskite structure. Since then, other Tc-perovskite structures have been synthesized, many by merely varying stoichiometric ratios in procedures that might otherwise yield spinel or pyrochlore $[20,21,113]$.

One such example is $\mathrm{CaTcO}_{3}$, which is made from high-temperature sintering in $\mathrm{Ar}$ at $1150^{\circ} \mathrm{C}$ for 4 hours [122]. Titanium analogues of Tc-perovskite structures exist, and with other mixed oxides, varying levels of Tc and Ti can be prepared. For example, $\operatorname{SrTi}_{0.9} \mathrm{Tc}_{0.1} \mathrm{O}_{3}$ was made by pressing oxides and firing at $1250^{\circ} \mathrm{C}$ for 24 hours [43]. Hartmann et al. [20] synthesized $\mathrm{SrTcO}_{3}$, the Tc end-member, under vacuum at $770^{\circ} \mathrm{C}$ for seven days, yielding particle sizes of $\sim 120 \mathrm{~nm}$. Then, $\mathrm{CdTcO}_{3}$ was synthesized by grinding $\mathrm{TcO}_{2}$ and $\mathrm{CdO}$ in methanol, followed by heating of this mixture in a fused quartz boat under flowing $\mathrm{Ar}$ gas at $850^{\circ} \mathrm{C}$. A similar method was used by Sasaki et al. [123] with high pressures and temperatures to make $\mathrm{CdTiO}_{3}$. Rodriguez [4] used the same approach to synthesize $\mathrm{SrTcO}_{3}$, except that $\mathrm{SrCO}_{3}$ was used instead of the divalent oxide to prevent hygroscopic moistening. As has already been mentioned, selfpropagating high temperature synthesis can create particles of perovskite, along with other mixed oxides $[112,113]$.

Rhenium perovskite phases analogous to the Tc species can be formed from $\mathrm{ReO}_{3}$ and divalent oxides heated to $1000^{\circ} \mathrm{C}$ for 24 hours in silica crucibles [124]. Cubic phases with the formula $\mathrm{Ba}\left(\mathrm{M}_{0.5} \mathrm{Re}_{0.5}\right) \mathrm{O}_{3}$ were synthesized, along with distorted $\mathrm{Sr}\left(\mathrm{Fe}_{0.5} \mathrm{Re}_{0.5}\right) \mathrm{O}_{3}$ and $\mathrm{Ca}\left(\mathrm{Fe}_{0.5} \mathrm{Re}_{0.5}\right) \mathrm{O}_{3}$. Except in the cases where $\mathrm{NiO}$ was a reagent, the products were pure. The 
phases made were reported to be insoluble in water and $\mathrm{HCl}$, slowly dissolving in nitric acid, and quickly dissolving in hydrogen peroxide.

Another study reports heating these perovskite phases in air to $1000^{\circ} \mathrm{C}$ [125], at which point the reagents oxidized and formed $(\mathrm{Ba}, \mathrm{Sr}){ }_{4} \mathrm{Re}_{2} \mathrm{MO}_{12}(\mathrm{M}=\mathrm{Mg}, \mathrm{Cd}, \mathrm{Co}, \mathrm{Zn})$. The $\operatorname{Sr}\left(\mathrm{Re}_{0.5} \mathrm{Ca}_{0.5}\right) \mathrm{O}_{3}$ form alone resisted oxidation in air at $1000^{\circ} \mathrm{C}$. There was no discussion of $\mathrm{Re}$ volatility, and the given stoichiometry implies that it remained in the new phase when it was formed. With no evidence that Re escaped the perovskite or product structure at $1000^{\circ} \mathrm{C}$, this implies that the volatility usually seen with Re species was inhibited by inclusion in the perovskite, which implies potential usefulness for possible Tc analogues for transporting Tc into the glass during melting.

Other, lower-temperature methods exist to synthesize perovskite. The previouslydescribed sol-gel method was used, starting from metal acetates [72]. Reagents were mineralized with $\mathrm{NH}_{4} \mathrm{OH}$ in a sol-gel and then heated to form perovskite. While peaks of the product were detected at $600^{\circ} \mathrm{C}$, the result was not pure perovskite until $1300^{\circ} \mathrm{C}$, a temperature $200^{\circ} \mathrm{C}$ lower than conventionally used for sintering. The reaction was complete in hours rather than days. Particle sizes were in the 10-nm range, as verified with TEM [72].

High-temperature sintering can be accomplished at lower temperatures by milling the precursors. Baek et al. [126] used a multi-ring mill that reduced media ablation during use. After milling, the mechano-chemically prepared mixture still required sintering at $850^{\circ} \mathrm{C}$. Crystallinity in samples milled in the ring mill increase to $>90 \%$ after sintering whereas unmilled samples and ball-milled samples were 8 and $10 \%$ crystalline, respectively, after the same heat treatment. This augmented crystallinity was seen across all heat treatments. Using basic metallic hydroxides and acidic metallic oxide pairs in the reagents increased the reactivity of the species and aided in the 
formation of complex oxide forms. By varying the stoichiometry of the starting reagents, pyrochlore-rich or pyrochlore-free perovskite were produced.

Urban et al. [127] synthesized ( $\mathrm{Sr}, \mathrm{Ba}) \mathrm{TiO}_{3}$ nanorods from bimetallic alkoxides and highly oxidizing aqueous solutions. Concentrated $\mathrm{H}_{2} \mathrm{O}_{2}$ decomposed the organic ligands on the metal at $280^{\circ} \mathrm{C}$ and precipitates out the nanorods, which were $60 \mathrm{~nm} \times 10 \mu \mathrm{m}$. This approach is a one-step, low temperature synthesis of the perovskite phase, but would be unlikely to capture $\mathrm{Tc}^{4+}$ in the Ti sites because of the very oxidizing conditions and the tendency of $\mathrm{Tc}^{4+}$ to oxidize to $\mathrm{Tc}^{7+}$ under this environment.

\subsection{Goethite}

Goethite is a mineral of the orthorhombic space group Pbnm and has the general formula of $\mathrm{AO}(\mathrm{OH})$ where $\mathrm{A}$ is one or a mix of metals but the most typical form is $\mathrm{FeO}(\mathrm{OH})$ as is shown in Figure 10 [128]. Goethite has been successfully prepared with Tc by means of an aqueous coprecipitation $[22,23]$ as Figure 12 illustrates. Divalent iron in solution with $\mathrm{Tc}^{7+}$ produced

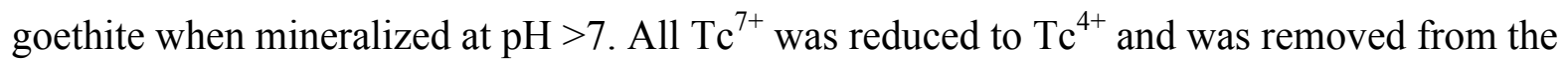

solution with the $\mathrm{Fe}^{2+}$, which oxidized to $\mathrm{Fe}^{3+}$. When further goethite-forming $\mathrm{Fe}\left(\mathrm{NO}_{3}\right)_{3}$ was added to 'armor' the goethite particles, very little Tc re-oxidation was observed in leaching tests. Goethite is one of only two Tc-bearing phases to be doped into LAW feed and melted into glass in crucible tests [129]. Preliminary results indicate that Tc retention was increased relative to tests where $\mathrm{KTcO}_{4}$ was used as a Tc source run in identical conditions.

\subsection{Layered Double Hydroxides}

Layered double hydroxides are metal hydroxides arranged in sheets with hydroxide ions, and have a formula $\mathrm{A}^{2+} \mathrm{B}^{3+}(\mathrm{OH})_{5}$. Examples such as fougerite (green rust) [24] and sulfide-based layered double hydroxides such as potassium metal sulfides (KMS-2) [15] have been observed to 
incorporate Tc. These are proposed as a route to remove Tc from liquid waste streams, and are able to pull Tc out of such solutions, although competition from other anions makes this method problematic [26] and low structural stability makes them less than ideal.

\subsection{Magnesium Phosphates}

Magnesium phosphates, such as ceramicrete and $\mathrm{MgKPO}_{4}$ were proposed as a Tc waste forms $[112,130]$. Reducing agents in the form of blast furnace slag or $\mathrm{SnCl}_{2}$ stabilize the $\mathrm{Tc}^{4+}$ which incorporates into the phosphate [26]. The reaction is exothermic and nearly instantaneous, and forms a monolithic solid with evenly dispersed Tc [131] Singh et al. [132] formed a Mg-K$\mathrm{PO}_{4}$ ceramic by adding a binding mixture $\left(\mathrm{MgO}+\mathrm{KH}_{2} \mathrm{PO}_{4}\right)$ to an aqueous solution of Tc with $1 \mathrm{M} \mathrm{NaOH}$ and $1 \mathrm{M}$ ethylenediamine in an anoxic environment. $\mathrm{SnCl}_{2}$ was added as reducing agent, and fly ash was added as a mechanical strengthener.

\subsection{Cementitous Waste}

Cementitous grouts, including saltstone and Cast Stone have been studied as matrices for Tc-containing waste. Saltstone was investigated by Savannah River National Laboratory to immobilize Tc, among other radionuclides in LAW [10]. Salt solutions of LAW are mixed with blast furnace slag, fly ash, and calcium hydroxide in a wide range of ratios to form cement. The cements were cured in water for several weeks. When $\mathrm{SnCl}_{2}$ is added as a reducing agent, the leaching rate of Tc from these matrices is lowered [15]. Portland cement, fly ash, and blast furnace slag mixed in different amounts were shown to effect performance, with fly ash promoting Tc reduction into $\mathrm{Tc}^{4+}$ and lowering leach rates by several orders of magnitude [9].Other Tc getters can be added to LAW solutions to pull Tc from solution, then kept in the waste during the cement-forming process [15]. A major drawback to cementitious waste forms is the vulnerability to re-oxidation. Lukens [133] showed that, while Tc remained as $\mathrm{Tc}^{4+}$ when 
cement was under anoxic conditions, after exposure to air, it reoxidized to $\mathrm{Tc}^{7+}$. This

vulnerability to re-oxidation makes cement a poor candidate to transport $\mathrm{Tc}^{4+}$ across the cold-cap and into glass melts.

\subsection{Metal Alloys}

Metallic Tc can be transmuted into $\mathrm{Ru}$ to a limited extent, or made into chemically durable waste forms [8]. Metallic Tc forms alloys with Fe, $\mathrm{Zr}, \mathrm{Mo}, \mathrm{Pd}, \mathrm{Rh}, \mathrm{Ru}$, and actinides $[134,135]$. The $\varepsilon$-metal is an alloy of Tc, $\mathrm{Mo}, \mathrm{Pd}, \mathrm{Rh}$, and $\mathrm{Ru}$ formed in nuclear fuel rods and in natural uranium fission [136]. Stainless steel alloys containing Zr have been made from spent fuel cladding hardware and noble metals from dissolved spent nuclear fuel where the Tc loading is around $\sim 2$ mass $\%$ and the Tc partitions into the ferrite and austenite phases rather than the $\mathrm{Zr}$ based intermetallic phases $[137,138]$. Methods for synthesizing Tc alloys include furnace melting, molten salt methods, arc melting, and hot pressing techniques (e.g., hot isostatic pressing, spark plasma sintering, and microwave sintering) [26, 27].

Additionally, direct electrolytic reduction of $\mathrm{TcO}_{4}{ }^{-}$from solutions to Tc metal such as off-gas scrubber streams has been shown to be unsatisfactory, yielding incomplete reduction and $\mathrm{Tc}^{4+}$ species [139], but has been demonstrated with some success on Hanford tank waste [140].

\section{Summary}

Technetium can be incorporated into a number of different solids including spinel, sodalite, rutile, tin dioxide, pyrochlore, perovskite, goethite, layered double hydroxides, cements, and alloys. Synthesis routes are possible for each of these phases, ranging from high-temperature ceramic sintering to ball-milling of constituent oxides. However, in practice, Tc has only been incorporated into solid materials by a limited number of the possible syntheses approaches. 
In this document, we provided a review of the diverse ways in which Tc-immobilizing materials can be made, showing the range of options available. In some cases, synthesis of the solids has been demonstrated in the literature with Tc; however, in other cases, it has not been demonstrated but likely could be synthesized using one or more of the techniques provided. The primary aim of this document is to provide a summary of the current state-of-the-art in making Tc-containing materials and materials that could act as a host for Tc.

\section{Acknowledgements}

This work was supported by the U.S. Department of Energy's Waste Treatment and Immobilization Plant Federal Project Office under the direction of Dr. Albert A. Kruger. Pacific Northwest National Laboratory is operated for the Department of Energy by Battelle Memorial Institute under contract DE-AC05-76RL01830. The authors would like to Dong-Sang Kim, Chuck Soderquist, Derek Dixon, and Wooyong Um for their guidance during this work.

\section{References}

[1] P. Certa, P. Empey, M. Wells. 2011. River Protection Project System Plan. ORP-11242, Rev. 6. DOE Office of River Protection, Richland, WA.

[2] V. Neck, B. Kanellakopulos, Radiochim. Acta 42 (3) (1987) 135-137.

[3] K. Morris, F.R. Livens, J.M. Charnock, I.T. Burke, J.M. McBeth, J.D.C. Begg, C. Boothman, J.R. Lloyd, Appl. Geochem. 23 (4) (2008) 603-617.

[4] E.E. Rodriguez, "Solid State Chemistry of Technetium and Rhenium Oxides," Ph.D. Thesis, University of California, Santa Barbara, 2009.

[5] J. Gibson, Radiochim. Acta 60 (2-3) (1993) 121-126.

[6] J.G. Darab, P.A. Smith, Chem. Mater. 8 (5) (1996) 1004-1021. 
[7] Y. Olsen, J.V. i Batlle, J. Environ. Radioact. 67 (3) (2003) 219-233.

[8] J. Bonnerot, V. Broudic, M. Phelip, C. Jégou, F. Varaine, X. Deschanels, M. Arnoux, J. Faugèrea, J. Nucl. Radiochem. Sci. 6 (3) (2005) 287-290.

[9] T.M. Gilliam, R.D. Spence, W.D. Bostick, J. Shoemaker, J. Hazard. Mater. 24 (2) (1990) 189-197.

[10] C. Langton, E. Wilhite, pp. 56, In the Proc. of INEt, 1988.

[11] R.J. Serne, J.H. Westsik. 2011. Data Package for Secondary Waste Form Down-SelectionCast Stone. PNNL-20706. Pacific Northwest National Laboratory, Richland, WA.

[12] D. Missimer, R. Rutherford. 2013. Preparation and Initial Characterization of Fluidized Bed Steam Reforming Pure-Phase Standards. SRNL-STI-2013-00111. Savannah River National Laboratory, Aiken, SC.

[13] S.V. Mattigod, R.J. Serne, G.E. Fryxell. 2003. Selection and Testing of "Getters" for Adsorption of Iodine-129 and Technetium-99: A Review. PNNL-14208. Pacific Northwest National Laboratory Richland, WA, Richland, WA.

[14] M. Morse, C. Nash. 2013. Experimental Ion Exchange Column With SuperLig 639 And Simulant Formulation. SRNL-L3100-2013-00157. Savannah River Site, Aiken, SC.

[15] N.P. Qafoku, J.J. Neeway, A.R. Lawter, T.G. Levitskaia, R.J. Serne, J.J. Westsik, M.M.V. Snyder. 2014. Technetium and Iodine Getters to Improve Cast Stone Performance. PNNL-23282. Pacific Northwest National Laboratory, Richland, WA.

[16] S.A. Luksic, B.J. Riley, D.-S. Kim, P. Hrma, M.J. Schweiger, W. Um, C.I. Pearce, C.Z. Soderquist. 2015. Use of mineral phases to increase Re and Tc retention in waste glass simulants. (in press) Pacific Northwest National Laboratory, Richland, WA.

[17] B. Kenna, P. Kuroda, J. Inorg. Nucl. Chem. 26 (4) (1964) 493-499. 
[18] M.J. den Exter, S. Neumann, T. Tomasberger, pp. 567-574, In the Proc. of Sci. Basis Nucl. Waste Manag. XXIX 932, Ed. P. Van Iseghem. Materials Research Society, 2006.

[19] T. Hartmann, A. Alaniz, F. Poineau, P. Weck, J. Valdez, M. Tang, G. Jarvinen, K. Czerwinski, K. Sickafus, J. Nucl. Mater. 411 (1) (2011) 60-71.

[20] T. Hartmann, A.J. Alaniz, D.J. Antonio, Procedia Chem. 7 (2012) 622-628.

[21] O. Muller, W.B. White, R. Roy, J. Inorg. Nucl. Chem. 26 (12) (1964) 2075-2086.

[22] W. Um, H.-s. Chang, J.P. Icenhower, W.W. Lukens, R.J. Serne, N.P. Qafoku, J.J. Westsik, E.C. Buck, S.C. Smith, Environ. Sci. Technol. 45 (11) (2011) 4904-1913.

[23] W. Um, H.-s. Chang, J.P. Icenhower, N. Qafoku, S.C. Smith, R.J. Serne, E.C. Buck, R.K. Kukkadapu, M.E. Bowden, J.H. Westsik. 2010. Immobilization and Limited Reoxidation of Technetium-99 by Fe (II)-Goethite. PNNL-19833. Pacific Northwest National Laboratory, Richland, WA.

[24] I. Alliot Llorens, P. Deniard, E. Gautron, A. Olicard, M. Fattahi, S. Jobic, B. Grambow, Radiochim. Acta 96 (9-11) (2008) 569-574.

[25] M. Kang, S. Rhee, H. Moon, V. Neck, T. Fanghanel, Radiochim. Acta 75 (3) (1996) 169173.

[26] J.J. Westsik, K. Cantrell, R. Serne, N. Qafoku. 2014. Technetium Immobilization Forms Literature Survey. PNNL-23329, EMSP-RPT-023. Pacific Northwest National Laboratory, Richland, WA.

[27] J.V. Crum, D. Strachan, A. Rohatgi, M. Zumhoff, J. Nucl. Mater. 441 (1-3) (2013) 103-112.

[28] W.W. Lukens, N. Magnani, T. Tyliszczak, D.K. Shuh. 2012. In Proc. of the American Chemical Society. DOE BES CSGB Review. 
[29] S.V. Mattigod, B. Peter McGrail, D.E. McCready, L.-Q. Wang, K.E. Parker, J.S. Young, Micropor. Mesopor. Mater. 91 (1-3) (2006) 139-144.

[30] R. Koivula, Cent. Eur. J. Chem. 8 (6) (2010) 1179-1184.

[31] I.L. Pegg, J. Radioanal. Nucl. Chem. (2015).

[32] W.W. Lukens, D.K. Shuh, N.C. Schroeder, K.R. Ashley, 38 (1) (2004) 229-233.

[33] J. Liu, C.I. Pearce, O. Qafoku, E. Arenholz, S.M. Heald, K.M. Rosso, 92 (2012) 67-81.

[34] J.K. Burdett, G.D. Price, S.L. Price, J. Am. Chem. Soc. 104 (1) (1982) 92-95.

[35] C.M.B. Henderson, J.M. Charnock, D.A. Plant, J. Phys.-Condens. Mat. 19 (7) (2007) 076214.

[36] T.A. Marshall, K. Morris, G.T.W. Law, J.F.W. Mosselmans, P. Bots, S.A. Parry, S. Shaw, Environ. Sci. Technol. 48 (20) (2014) 11853-11862.

[37] C.I. Pearce, C.M.B. Henderson, N.D. Telling, R.A.D. Pattrick, J.M. Charnock, V.S. Coker, E. Arenholz, F. Tuna, G. van der Laan, Am. Mineral. 95 (2010) 425-439.

[38] S.W.A. Bligh, P.J. Sadler, J.A. Marriott, I.A. Latham, J.D. Kelly, Int. J. Radiat. Appl. Instrum. Part A 40 (9) (1989) 751-757.

[39] U. Colombo, F. Gazzarrini, G. Lanzavecchia, G. Sironi, Science 147 (3661) (1965) 1033.

[40] S. Laurent, D. Forge, M. Port, A. Roch, C. Robic, L. Vander Elst, R.N. Muller, Chem. Rev. 108 (6) (2008) 2064-2110.

[41] F.N. Skomurski, K.M. Rosso, K.M. Krupka, B.P. McGrail, Environ. Sci. Technol. 44 (15) (2010) 5855-5861.

[42] W.J. Deutsch, K.J. Cantrell, K.M. Krupka, M.L. Lindberg, R. Jeffery Serne, Appl. Geochem. 26 (9-10) (2011) 1681-1693. 
[43] M.Y. Khalil, W.B. White, pp. 655-662, In the Proc. of Sci. Basis Nucl. Waste Manag. VII 26, Ed. G. L. McVay. Elsevier, 1984.

[44] G.J. Thorogood, Z. Zhang, J.R. Hester, B.J. Kennedy, J. Ting, C.J. Glover, B. Johannessen, Dalton Trans. 40 (41) (2011) 10924-10926.

[45] W. Um, S. Luksic, G. Wang, D.-S. Kim, M. Schweiger, P. Hrma, A. Kruger, In the Proc. of Waste Manag. (in press), 2015.

[46] D. Chen, D. Chen, X. Jiao, Y. Zhao, M. He, Powder Technol. 133 (1) (2003) 247-250.

[47] S.A. Luksic, B.J. Riley. 2015. Molten Salt Synthesis of Spinel. (in press) Pacific Northwest National Laboratory, Richland, WA.

[48] P. Laokul, V. Amornkitbamrung, S. Seraphin, S. Maensiri, Curr. Appl. Phys. 11 (1) (2011) 101-108.

[49] S. Bid, P. Sahu, S. Pradhan, Physica E 39 (2) (2007) 175-184.

[50] J. Calbo, M. Tena, G. Monrós, M. Llusar, J. Badenes, J. Sol-Gel Sci. Technol. 38 (2) (2006) 167-177.

[51] M.Y. Khalil, W.B. White, J. Am. Ceram. Soc. 66 (10) (1983) c197-c198.

[52] H.T. Kim, Y. Kim, M. Valant, D. Suvorov, J. Am. Ceram. Soc. 84 (5) (2001) 1081-1086.

[53] E.E. Rodriguez, F. Poineau, A. Llobet, A.P. Sattelberger, J. Bhattacharjee, U.V. Waghmare, T. Hartmann, A.K. Cheetham, J. Am. Chem. Soc. 129 (33) (2007) 10244-10248.

[54] K. Righter, pp. 1759, In the Proc. of Lunar and Planetary Institute Science Conference Abstracts, 32, 2001.

[55] S.B. Shirey, R.J. Walker, Anal. Chem. 67 (13) (1995) 2136-2141.

[56] J. Chen, C. Sorensen, K. Klabunde, G. Hadjipanayis, E. Devlin, A. Kostikas, Phys. Rev. B 54 (13) (1996) 9288-9296. 
[57] C.I. Pearce, O. Qafoku, J. Liu, E. Arenholz, S.M. Heald, R.K. Kukkadapu, C.A. Gorski, C.M.B. Henderson, K.M. Rosso, J. Colloid Interface Sci. 387 (1) (2012) 24-38.

[58] C.R. Vestal, Z.J. Zhang, Nano Lett. 3 (12) (2003) 1739-1743.

[59] C. Liu, B. Zou, A.J. Rondinone, Z.J. Zhang, J. Phys. Chem. B 104 (6) (2000) 1141-1145.

[60] O. Perales-Perez, Y. Umetsu, Hydrometallurgy 55 (1) (2000) 35-56.

[61] N. Gribanov, E. Bibik, O. Buzunov, V. Naumov, J. Magn. Magn. Mater. 85 (1) (1990) 7-10.

[62] M. Hirano, S. Okumura, Y. Hasegawa, M. Inagaki, J. Solid State Chem. 168 (1) (2002) 510.

[63] Y.-I. Jang, H. Wang, Y.-M. Chiang, J. Mater. Chem. 8 (12) (1998) 2761-2764.

[64] G. Gnanaprakash, S. Mahadevan, T. Jayakumar, P. Kalyanasundaram, J. Philip, B. Raj, Mater. Chem. Phys. 103 (1) (2007) 168-175.

[65] A.S. Albuquerque, J.D. Ardisson, W.A. Macedo, M. Alves, J. Appl. Phys. 87 (9) (2000) $4352-4357$.

[66] B. Domenichini, D. Aymes, P. Perriat, B. Gillot, Mater. Chem. Phys. 39 (1) (1994) 80-84.

[67] I. Martínez-Mera, M. Espinosa-Pesqueira, R. Pérez-Hernández, J. Arenas-Alatorre, Mater. Lett. 61 (23) (2007) 4447-4451.

[68] D. Gherca, A. Pui, N. Cornei, A. Cojocariu, V. Nica, O. Caltun, J. Magn. Magn. Mater. 324 (22) (2012) 3906-3911.

[69] P. Poddar, H. Srikanth, S. Morrison, E. Carpenter, J. Magn. Magn. Mater. 288 (2005) 443451.

[70] C. Liu, A.J. Rondinone, Z.J. Zhang, Pure Appl. Chem. 72 (1) (2000) 37-45.

[71] T. Giannakopoulou, L. Kompotiatis, A. Kontogeorgakos, G. Kordas, J. Magn. Magn. Mater. 246 (3) (2002) 360-365. 
[72] K. Huang, M. Feng, J.B. Goodenough, J. Am. Ceram. Soc. 79 (4) (1996) 1100-1104.

[73] Q. Song, Z.J. Zhang, J. Am. Chem. Soc. 126 (19) (2004) 6164-6168.

[74] Q. Song, Y. Ding, Z.L. Wang, Z.J. Zhang, Chem. Mater. 19 (19) (2007) 4633-4638.

[75] Q. Song, Z.J. Zhang, J. Am. Chem. Soc. 134 (24) (2012) 10182-10190.

[76] L. Pérez-Mirabet, E. Solano, F. Martínez-Julián, R. Guzmán, J. Arbiol, T. Puig, X. Obradors, A. Pomar, R. Yáñez, J. Ros, Mater. Res. Bull. 48 (3) (2013) 966-972.

[77] J.-F. Pasquier, S. Komarneni, R. Roy, J. Mater. Sci. 26 (14) (1991) 3797-3802.

[78] V. Kuznetsova, O. Almjasheva, V. Gusarov, Glass Phys. Chem. 35 (2) (2009) 205-209.

[79] M. Sisk, I. Kilbride, A. Barker, J. Mater. Sci. Lett. 14 (3) (1995) 153-154.

[80] J. Zhang, J. Shi, M. Gong, J. Solid State Chem. 182 (8) (2009) 2135-2140.

[81] Z. Xing, Z. Ju, J. Yang, H. Xu, Y. Qian, Nano Res. 5 (7) (2012) 477-485.

[82] A.R. Gainsford, M.J. Sisley, T.W. Swaddle, P. Bayliss, Can. J. Chem. 53 (1) (1975) 12-19.

[83] A. Alarifi, N. Deraz, S. Shaban, J. Alloy. Compd. 486 (1-2) (2009) 501-506.

[84] M.J. Geselbracht, L.D. Noailles, L.T. Ngo, J.H. Pikul, R.I. Walton, E.S. Cowell, F. Millange, D. O'Hare, Chem. Mater. 16 (6) (2004) 1153-1159.

[85] T. Kimura, Molten Salt Synthesis of Ceramic Powders. In Advances in Ceramics - Synthesis and Characterization, Processing and Specific Applications. Edited by C. Sikalidis. InTech, 2011.

[86] P. Afanasiev, C. Geantet, Coordin. Chem. Rev. 178 (2) (1998) 1725-1752.

[87] B. Senthilkumar, R. Kalai Selvan, P. Vinothbabu, I. Perelshtein, A. Gedanken, Mater. Chem. Phys. 130 (1) (2011) 285-292.

[88] S. Ziemniak, A. Gaddipati, P. Sander, S. Rice, J. Phys. Chem. Solids 68 (8) (2007) 14761490. 
[89] S.L. Darshane, S. Suryavanshi, I. Mulla, Ceram. Int. 35 (5) (2009) 1793-1797.

[90] S. Zhang, J. Pak. Mater. Soc. 1 (2) (2007) 49-53.

[91] Y. Hayashi, T. Kimura, T. Yamaguchi, J. Mater. Sci. 21 (8) (1986) 2876-2880.

[92] D. Su, M. Ford, G. Wang, Sci. Rep. 2 (924) (2012) 1-7.

[93] Č. Jovalekić, M. Zdujić, A. Radaković, M. Mitrić, Mater. Lett. 24 (6) (1995) 365-368.

[94] M. Zdujić, O. Milošević, L.Č. Karanović, Mater. Lett. 13 (2) (1992) 125-129.

[95] D. Domanski, G. Urretavizcaya, F.J. Castro, F.C. Gennari, J. Am. Ceram. Soc. 87 (11) (2004) 2020-2024.

[96] E. Yalamaç, S. Akkurt, M. Çiftçioğlu, Key Eng. Mater. 264 (2004) 53-56.

[97] C. Henderson, D. Taylor, Spectrochim. Acta, Part A 33 (3) (1977) 283-290.

[98] M. Fechtelkord, Solid State Nucl. Magn. Reson. 18 (1) (2000) 70-88.

[99] J.O. Dickson, J.B. Harsh, M. Flury, W.W. Lukens, E.M. Pierce, Environ. Sci. Technol. 48 (21) (2014) 12851-12857.

[100] W.C. Lepry, B.J. Riley, J.V. Crum, C.P. Rodriguez, D.A. Pierce, J. Nucl. Mater. 442 (1) (2013) 350-359.

[101] I. Hassan, D. Grundy, Can. Mineral. 27 (1989) 165-172.

[102] L. Heller-Kallai, I. Lapides, Appl. Clay Sci. 35 (1) (2007) 99-107.

[103] B. Marinder, A. Magneli, Acta Chem. Scand. 12 (1958) 1153-1158.

[104] M. Stewart, E. Vance, R. Day, pp. WM-4362, In the Proc. of Proc. Waste Manage. Symp., 2004.

[105] Y. Iida, S. Ozaki, J. Am. Ceram. Soc. 44 (3) (1961) 120-127.

[106] E.F. Heald, C.W. Weiss, Am. Mineral. 57 (1-2) (1972) 10-23.

[107] K. MacKenzie, Trans. J. Br. Ceram. Soc. 74 (2) (1975) 29-34. 
[108] K. Mackenzie, Trans. J. Br. Ceram. Soc. 74 (3) (1975) 77-84.

[109] K. MacKenzie, Trans. J. Br. Ceram. Soc. 74 (4) (1975) 121-125.

[110] K. MacKenzie, Trans. J. Br. Ceram. Soc. 74 (4) (1975) 127-134.

[111] Y. Fu, Z. Jin, Y. Ni, H. Du, T. Wang, Thin Solid Films 517 (19) (2009) 5634-5640.

[112] N. Laverov, S. Yudintsev, B. Omel'yanenko, Geol. Ore Deposits 51 (4) (2009) 259-274.

[113] N. Laverov, S. Yudintsev, E. Konovalov, T. Mishevets, B. Nikonov, B. Omel'yanenko, Dokl. Chem. 431 (1) (2010) 71-75.

[114] N. Laverov, S. Yudintsev, T. Livshits, S. Stefanovsky, A. Lukinykh, R. Ewing, Geochem. Int. 48 (1) (2010) 1-14.

[115] J. Rockenberger, U. Zum Felde, M. Tischer, L. Tröger, M. Haase, H. Weller, J. Chem. Phys. 112 (9) (2000) 4296-4304.

[116] R. Koivula, R. Harjula, Sep. Sci. Technol. 46 (2) (2010) 315-320.

[117] Y.I. Korneyko, In the Proc. of 7th International Symposium on Technetium and Rhenium, 44, Ed. K. E. German, B. F. Myasoedov, G. E. Kodina, I. D. Troshkina, and T. Sekine. Granitsa Publishing House, 2011.

[118] H. Nyman, S. Andersson, B. Hyde, M. O'Keeffe, J. Solid State Chem. 26 (2) (1978) 123131.

[119] P.C. Donohue, J.M. Longo, R.D. Rosenstein, L. Katz, Inorg. Chem. 4 (8) (1965) $1152-$ 1153.

[120] J. Zeng, H. Wang, Y. Zhang, M.K. Zhu, H. Yan, J. Phys. Chem. C. 111 (32) (2007) 1187911887.

[121] A.F. Fuentes, K. Boulahya, M. Maczka, J. Hanuza, U. Amador, Solid State Sci. 7 (4) (2005) 343-353. 
[122] M. Avdeev, G.J. Thorogood, M.L. Carter, B.J. Kennedy, J. Ting, D.J. Singh, K.S. Wallwork, J. Am. Chem. Soc. 133 (6) (2011) 1654-1657.

[123] S. Sasaki, C.T. Prewitt, J.D. Bass, W. Schulze, Acta Cryst. C 43 (9) (1987) 1668-1674.

[124] J. Longo, R. Ward, J. Am. Chem. Soc. 83 (13) (1961) 2816-2818.

[125] J.M. Longo, L. Katz, R. Ward, Inorg. Chem. 4 (2) (1965) 235-241.

[126] J.G. Baek, T. Isobe, M. Senna, J. Am. Ceram. Soc. 80 (4) (1997) 973-981.

[127] J.J. Urban, W.S. Yun, Q. Gu, H. Park, J. Am. Chem. Soc. 124 (7) (2002) 1186-1187.

[128] H.X. Yang, R. Lu, R.T. Downs, G. Costin, Acta Cryst. E. 62 (2006) i250-i252.

[129] W. Um, S.A. Luksic, P. Hrma, In the Proc. of Waste Manag., (in press), 2015.

[130] A. Wagh, M. Maloney, G. Thomson, A. Antink, 3 (2003).

[131] S. Vinokurov, Y.M. Kulyako, O. Slyuntchev, S. Rovny, B. Myasoedov, J. Nucl. Mater. 385 (1) (2009) 189-192.

[132] D. Singh, V. Mandalika, S. Parulekar, A. Wagh, J. Nucl. Mater. 348 (3) (2006) 272-282.

[133] W.W. Lukens, J.J. Bucher, D.K. Shuh, N.M. Edelstein, Environ. Sci. Technol. 39 (20) (2005) 8064-8070.

[134] J.V. Crum, D. Strachan, A. Rohatgi, M. Zumhoff, 441 (1) (2013) 103-112.

[135] C.D. Taylor, J. Metall. 2011 (2011) 1-8.

[136] S. Utsunomiya, R.C. Ewing, Radiochim. Acta 94 (9-11) (2006) 749-753.

[137] D.D. Keiser Jr, D.P. Abraham, J.W. Richardson Jr, J. Nucl. Mater. 277 (2-3) (2000) 333338.

[138] S.M. McDeavitt, D.P. Abraham, J.Y. Park, J. Nucl. Mater. 257 (1) (1998) 21-34.

[139] J. Eakins, D. Humphries, J. Inorg. Nucl. Chem. 25 (6) (1963) 737. 
[140] W.E. Lawrence, D.L.J. Blanchard, D.E. Kurath. 1997. Electrochemical reduction removal of technetium-99 from Hanford tank wastes. PNNL-11696. Pacific Northwest National Laboratory, Richland, WA.

[141] F. Bosi, U. Hålenius, H. Skogby, Am. Mineral. 94 (1) (2009) 181-189.

[142] C.M.B. Henderson, K.S. Neuhoff, A.R. Lennie, Open Mineral. J. 3 (2009) 1-11.

[143] G.J. Thorogood, M. Avdeev, M.L. Carter, B.J. Kennedy, J. Ting, K.S. Wallwork, Dalton Trans. 40 (27) (2011) 7228-7233. 
Tables

Table 1. Summary of mineral structures discussed in this review as well as chemical composition, space group, and theoretical Tc loading for each structure.

\begin{tabular}{|l|l|l|c|c|c|}
\hline $\begin{array}{l}\text { Mineral } \\
\text { name }\end{array}$ & $\begin{array}{l}\text { Mineral chemical } \\
\text { formula }\end{array}$ & $\begin{array}{l}\text { Space } \\
\text { group }\end{array}$ & $\begin{array}{l}\text { Theoretical } \\
\text { Tc loading } \\
\text { (mass\% })\end{array}$ & $\begin{array}{l}\text { Demonstrated } \\
\text { Tc loading } \\
\text { (mass\%) }\end{array}$ & $\begin{array}{l}\text { Reference or } \\
\text { related } \\
\text { reference }\end{array}$ \\
\hline Trevorite & $\mathrm{NiFe}_{2} \mathrm{O}_{4}$ & $F d 3 m$ & $4.4 \%$ & $4.4 \%$ & {$[28,141]$} \\
\hline Tc spinel & $\mathrm{Mg}_{2} \mathrm{TcO}_{4}$ & $F d 3 m$ & $36 \%$ & $47 \%$ & {$[21]$} \\
\hline Sodalite & $\mathrm{Na}_{8}\left(\mathrm{AlSiO}_{4}\right)_{6}\left(\mathrm{TcO}_{4}\right)_{2}$ & & $16 \%$ & $1.1 \%$ & {$[12,29]$} \\
\hline Rutile & $\mathrm{Ti}_{0.6} \mathrm{Tc}_{0.4} \mathrm{O}_{2}$ & $P 4_{2} / m n m$ & $39 \%$ & $39 \%$ & {$[21]$} \\
\hline Tin dioxide & $\mathrm{Sn}_{(\mathrm{Tc}) \mathrm{O}_{2}}$ & $P 4_{2} / m n m$ & $3.1 \%$ & $0.0079 \%$ & {$[30]$} \\
\hline Pyrochlore & $\mathrm{Cd}_{2} \mathrm{Tc}_{2} \mathrm{O}_{7}$ & $F d 3 m$ & $\sim 37 \%$ & $37 \%$ & {$[19]$} \\
\hline Perovskite & $\mathrm{SrTcO}_{3}$ & $P n m a$ & $42 \%$ & $42 \%$ & {$[4,21]$} \\
\hline Goethite & $\mathrm{FeO}_{2}(\mathrm{OH})$ & $P b n m$ & unknown & $0.5 \%$ & {$[23]$} \\
\hline $\begin{array}{l}\text { Layered } \\
\text { double } \\
\text { hydroxides }\end{array}$ & $\mathrm{Mg}_{6} \mathrm{Al}_{2}(\mathrm{OH})_{17} \mathrm{TcO}_{4}$ & & $15 \%$ & $15 \%$ & {$[25]$} \\
\hline
\end{tabular}


Figures

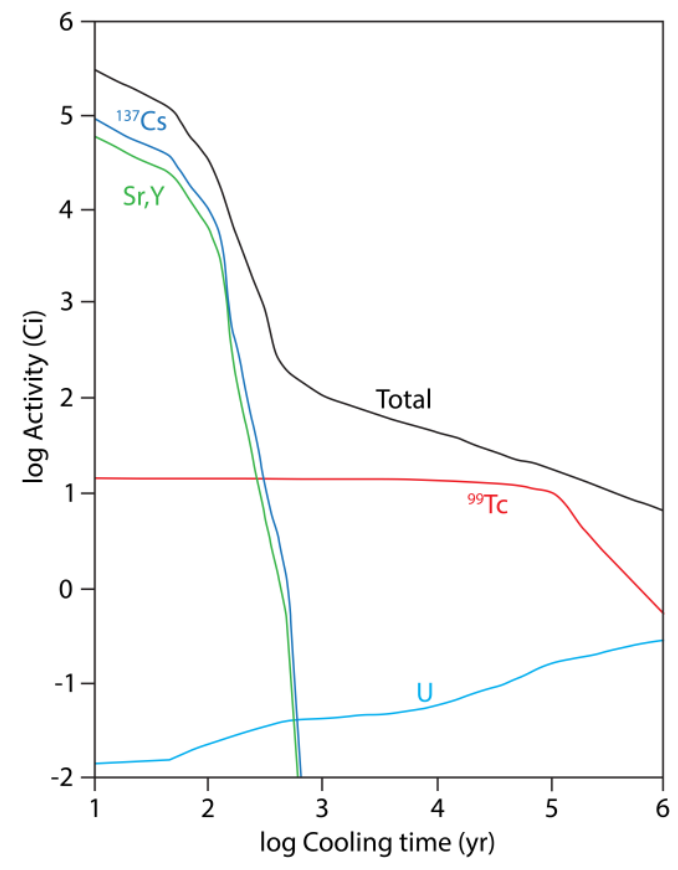

Figure 1. Log/log plot of the activity (in $\mathrm{Ci}$ ) of major radionuclides in high-level nuclear waste vs. time (in years) [4]. 


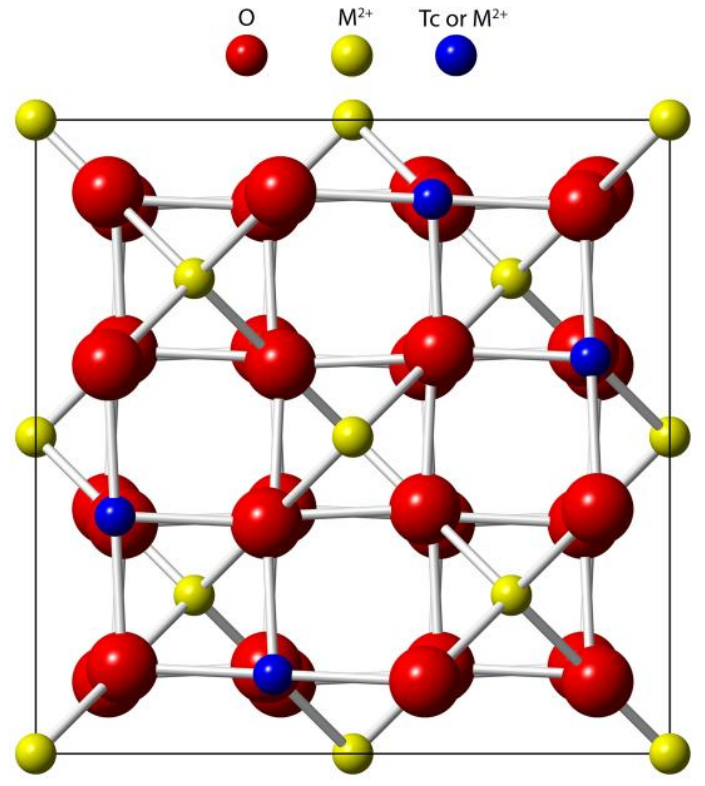

Figure 2. Model of ulvöspinelunit cell of $\mathrm{Fe}_{2}{ }^{2+} \mathrm{TiO}_{4}$ (where $\mathrm{Ti}$ can be $\mathrm{Tc}$ ) after Muller et al.[21]. The structure is shown normal to the $a$ direction. 

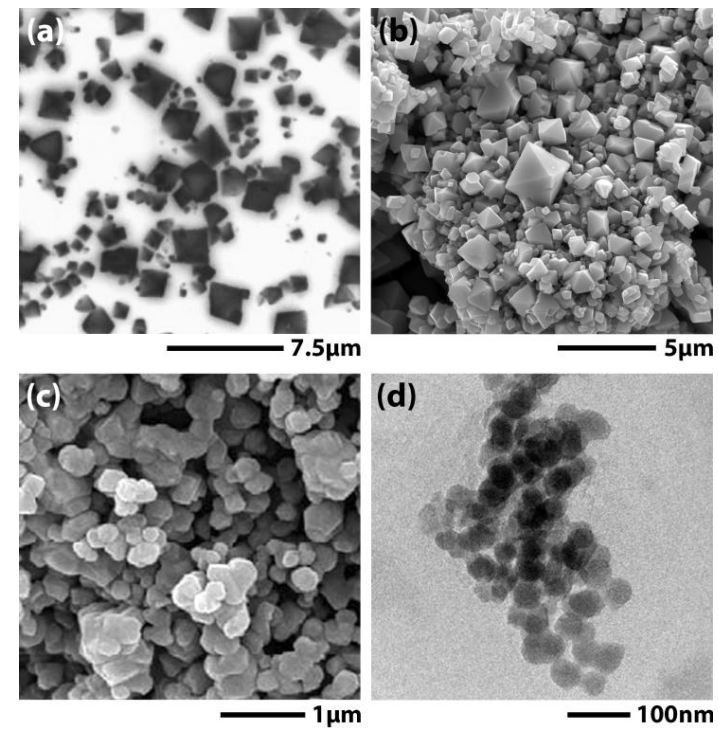

Figure 3. SEM and TEM micrographs of spinel of various sizes including (a) large spinel made hydrothermally [46], (b) large spinel made with molten salt synthesis [47], (c) medium made by aqueous precipitation [48], and (d) small spinel made with ball-milling [49]. 


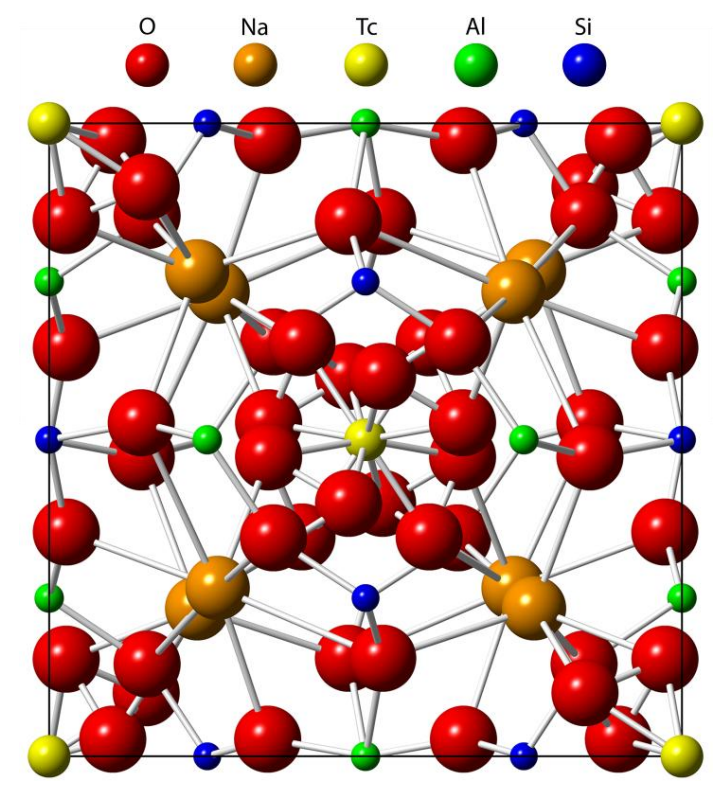

Figure 4. Theoretical model of Tc-containing sodalite unit cell of the formula $\mathrm{Na}_{8}\left(\mathrm{AlSiO}_{4}\right)_{6}\left(\mathrm{TcO}_{4}\right)_{2}$ after the perrhenate sodalite by Mattigod et al.[29]. The structure is shown normal to the $a$ direction. 

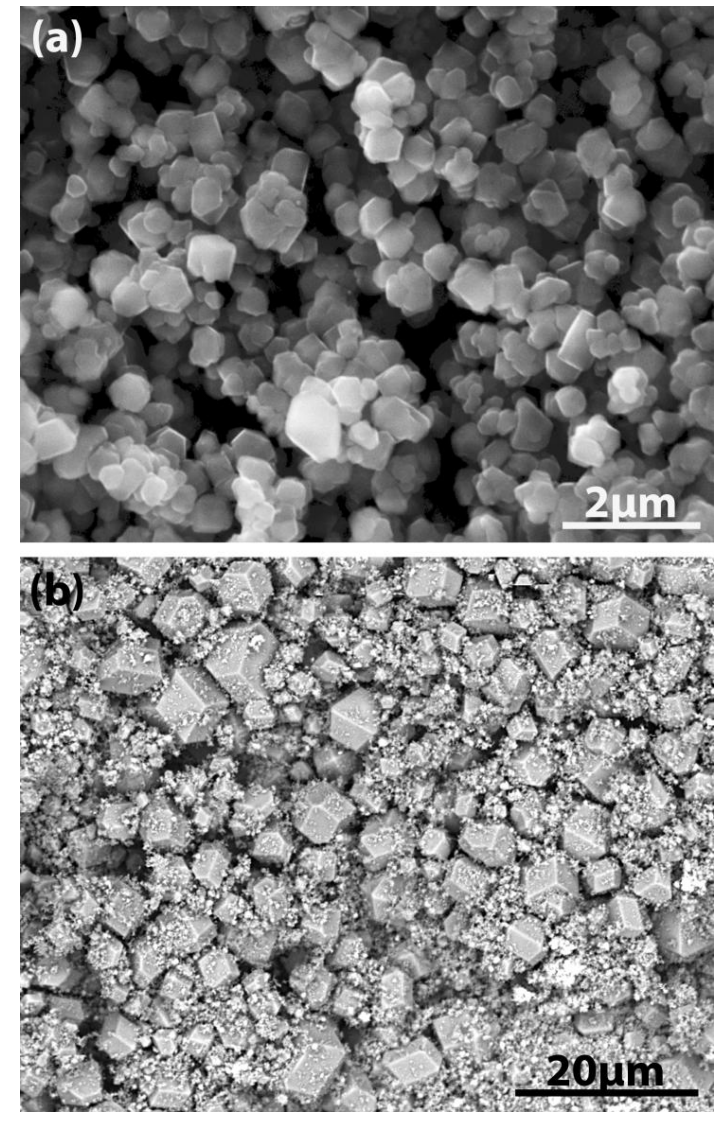

Figure 5. SEM micrographs of (a) Tc-sodalite [12] and (b) Re-sodalite [16]. 


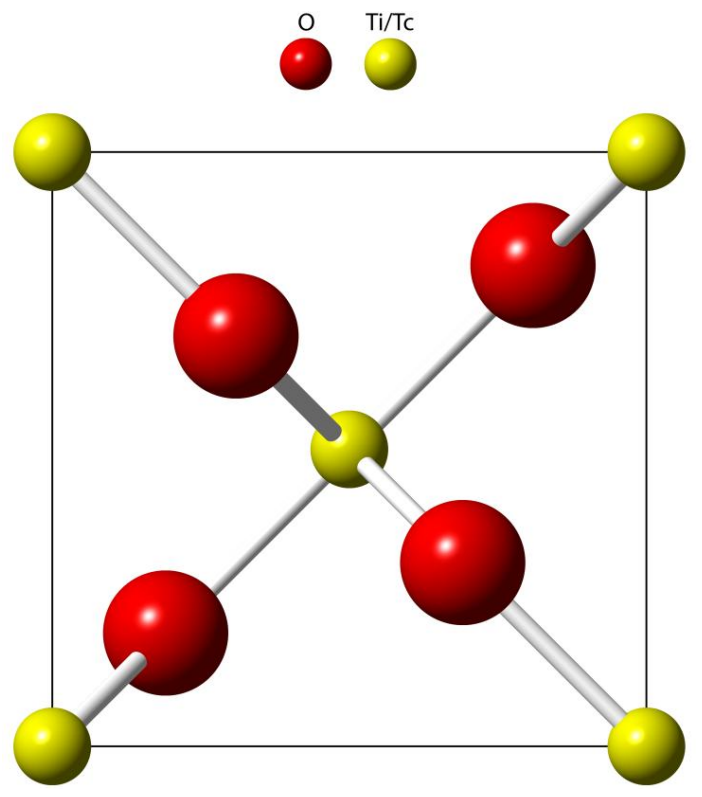

Figure 6. Model of $\mathrm{Tc}$ replacing $\mathrm{Ti}$ in rutile $\left(\mathrm{TiO}_{2}\right)$ unit cell. The structure, from Henderson et al. [142], is shown normal to the $c$ direction. 


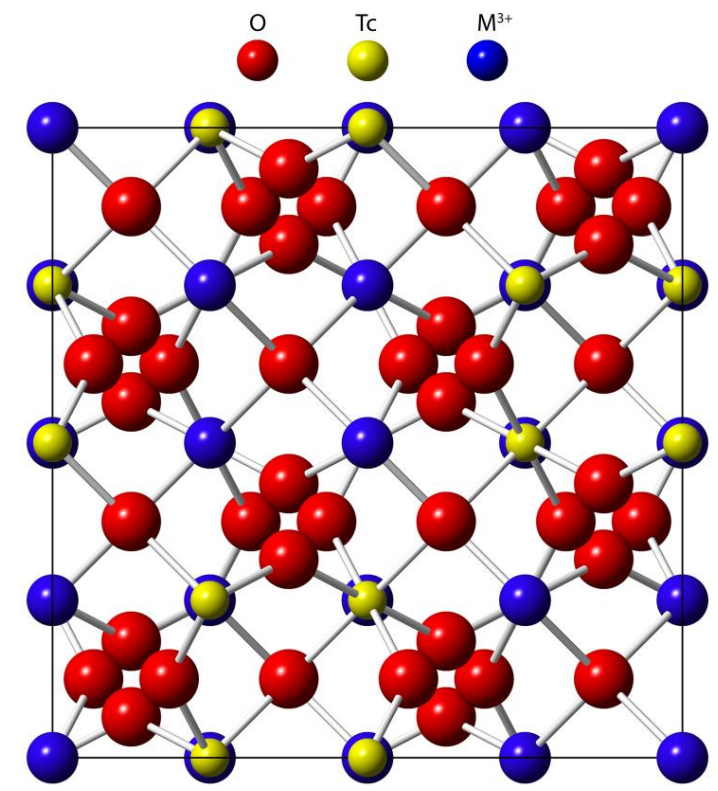

Figure 7. Model of a pyrochlore unit cell based off of $D y_{2} \mathrm{Tc}_{2} \mathrm{O}_{7}$ by Muller et al. [21]. The structure is shown normal to the $a$ direction.

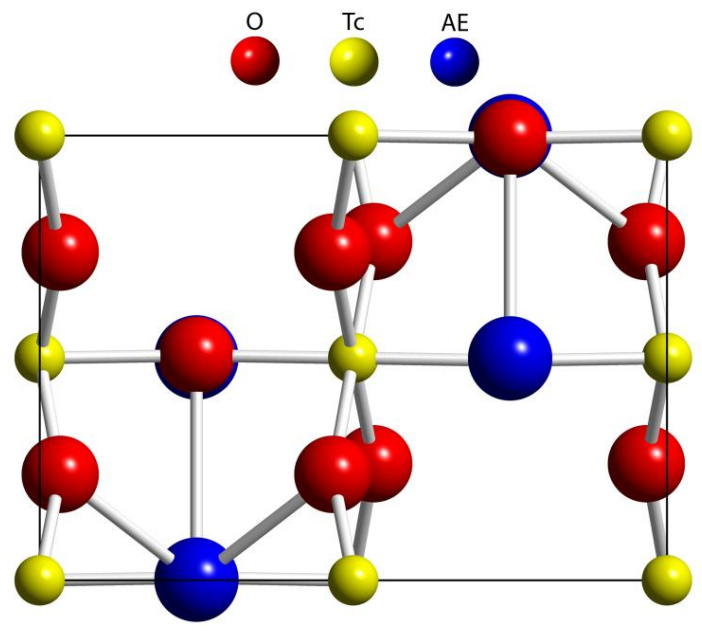

Figure 8. Model of a $\mathrm{SrTcO}_{3}$ perovskite unit cellafter Thorogood et al. [143]. The structure is shown normal to the $c$ direction. 


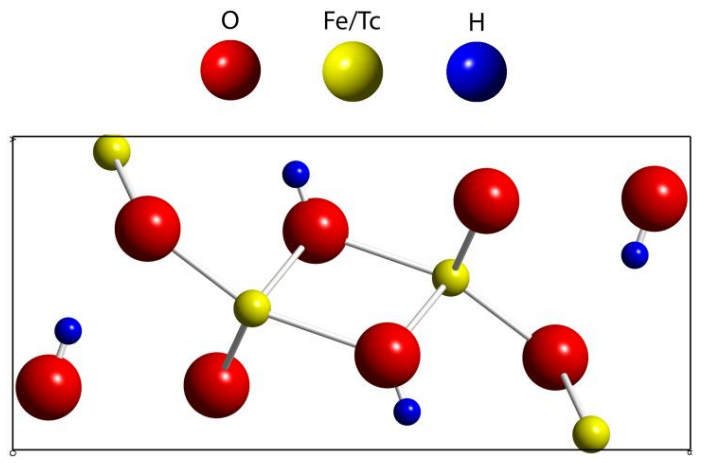

Figure 9. Model of a $\mathrm{FeO}(\mathrm{OH})$ (goethite) unit cellafter Yang et al.[128] where Tc can substitute into the structure for $\mathrm{Fe}^{3+}$. The structure is shown normal to the $c$ direction. 

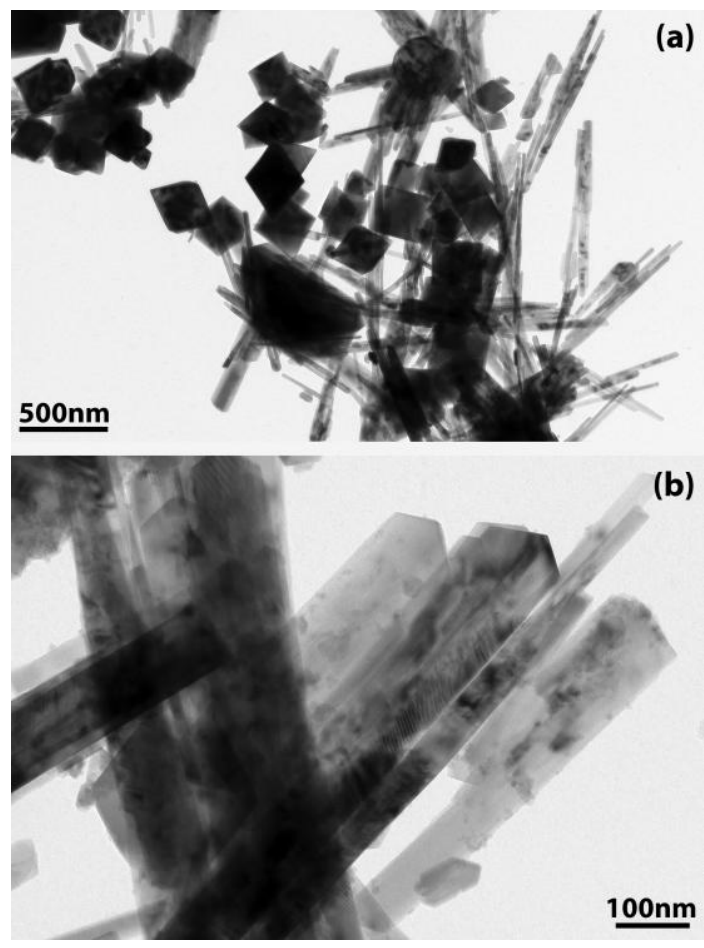

Figure 10. TEM micrographs of (a) goethite (rods) with magnetite (octahedral) at and (b) goethite [22, 23]. 